\title{
Exploring the potential for biomethane production by willow pyrolysis using life cycle assessment methodology
}

\author{
Elham Ahmadi Moghaddam*, Niclas Ericsson, Per-Anders Hansson and Åke Nordberg
}

\begin{abstract}
Background: Biomethane, as a potential substitute for natural gas, reduces the use of fossil-based sources, promoting bioenergy applications. Biomethane for energy use can be produced using a variety of biomass types and technologies. Biomethane from farmland crops is currently produced by anaerobic digestion (AD) of energy crops, which is a biological treatment of organic material resulting in biomethane and digestate. Recently, thermochemical conversion technologies of biomass to biomethane have gained attention. Pyrolysis is a thermochemical process whereby woody biomass is converted to fuel gas and biochar. This study assessed the land use efficiency of producing biomethane through a maize-based AD system compared with switching to a willow-based biomethane system using pyrolysis as an emerging technology. The energy performance and climate impact of the two pathways were assessed from a land use perspective, using life cycle assessment methodology. The entire technical system, from biomass production to delivery of biomethane as the end product, was included within the analysis. The study also investigated how the climate impact was affected when biochar was applied to soil to act as a soil amendment and carbon sequestration agent or when biochar was used as an energy source.
\end{abstract}

Results: Pyrolysis of willow had a higher external energy ratio and climate mitigation effect than maize-based AD as a result of lower primary energy inputs and lower methane loss in the pyrolysis process and upgrading units. Furthermore, the biochar from willow pyrolysis, when used as a soil amendment or energy source, contributed significantly to the climate impact mitigation potential in both cases. Substituting fossil gas with biomethane gave a considerable reduction in climate impact in all scenarios, especially in the case of willow pyrolysis. The willow pyrolysis system acted as a carbon sink, resulting in a negative climate impact, counteracting global warming.

Conclusion: From a land use perspective, the transition from maize-based AD to a willow-based pyrolysis system for biomethane production could be beneficial regarding the energy performance and climate impact. Application of biochar to the soil in the willow scenario contributed significantly to counteracting emissions of greenhouse gases.

Keywords: Anaerobic digestion, Maize, Willow, Pyrolysis, Life cycle assessment, Biochar

\section{Background}

Rising global demand for energy, accompanied by declining fossil fuel reserves and increasing global warming, has focused the attention of policymakers on a sustainable supply of reliable and accessible energy. Two main strategic approaches for simultaneously addressing the issues of high energy demand and climate change mitigation are (i) use of renewable energy and (ii) improved energy

* Correspondence: Elham.Ahmadi.Moghaddam@slu.se

Department of Energy and Technology, Swedish University of Agricultural Sciences (SLU), P.O. Box 7032, 75007 Uppsala, Sweden efficiency in energy production and utilization. Biomass is considered an important renewable energy resource, as it is locally available, abundant, and technically flexible in energy production.

Biogas, mainly a mix of methane $\left(\mathrm{CH}_{4}\right)$ and carbon dioxide $\left(\mathrm{CO}_{2}\right)$, is a renewable energy gas sourced from biomass and produced using either biological or thermochemical processes. Biomethane, obtained after upgrading biogas to $>97 \% \mathrm{CH}_{4}$, is an appropriate substitute for fossil natural gas in heat and power generation and as a vehicle fuel. A growing number of countries are offering prospects and setting obligations to replace part

(c) The Author(s). 2019 Open Access This article is distributed under the terms of the Creative Commons Attribution 4.0 International License (http://creativecommons.org/licenses/by/4.0/), which permits unrestricted use, distribution, and reproduction in any medium, provided you give appropriate credit to the original author(s) and the source, provide a link to the Creative Commons license, and indicate if changes were made. 
of their fossil natural gas consumption with renewable fuels, in order to reduce greenhouse gas (GHG) emissions [1]. In Sweden, biogas can contribute to meeting ambitious targets on decreasing GHG emissions and increasing the share of renewables in different sectors, such as industry, transport, and households, which face major challenges in phasing out fossil fuels [2]. In 2016, annual consumption of biogas in Sweden was $2 \mathrm{TWh}$, of which $64 \%$ was upgraded to biomethane $\left(97 \% \mathrm{CH}_{4}\right)$ for the use in the transport sector. During the same year, the total use of natural gas decreased to 10.4 TWh compared with 18.7 TWh in 2015 [3].

Anaerobic digestion (AD) is the biological conversion of biomass to biogas and is mainly associated with the treatment of animal manure and sewage sludge. The limited production rate and methane yield of these feedstocks have led to the introduction of energy-rich co-feedstocks in order to increase biogas production. Among high-yielding co-feedstocks, energy crops suitable for $\mathrm{AD}$ are important. Maize silage provides high biomass yield (10-30 Mg dry matter (DM)/ha), has a high methane yield $\left(370 \mathrm{Nm}^{3} / \mathrm{Mg}\right.$ organic matter $(\mathrm{OM})$ according to [4]), and has the lowest GHG emissions of all main AD energy crops [5, 6]. Maize cultivation is expanding in northern European countries as an adaptation to the increasing temperatures, aided by the global warming effect, creating a need to manage this crop and its residues [7-9]. The residue from $\mathrm{AD}$ (digestate) is used as a nutrient source, decreasing the need for energy-intensive mineral fertilizers and consequently reducing GHG emissions [10]. In addition, the organic fraction of the digestate can contribute to soil organic matter (SOM), influencing soil biological, chemical, and physical characteristics [11].

Lignocellulosic or woody biomass is one of the most abundant organic materials and an attractive renewable bioenergy source. Anaerobic digestion (AD) of woody biomass is not considered technically feasible, due to many factors that mainly influence the anaerobic biodegradability of wood such as particle size, compact structure, proportion of structural and non-structural carbohydrates, low moisture content, low wood-to-bark ratio, and toxic components [12]. In order to anaerobically digest woody biomass, different pre-treatment methods, such as biological, chemical, mechanical, and thermal processes, are needed $[12,13]$. These processes require additional inputs and are complicated and costly [14]. Thermochemical conversion by pyrolysis and gasification are emerging technologies for conversion of woody biomass to syngas, which can be further reformed to methane [15-17]. Pyrolysis operates at moderate temperatures (between 400 and $800{ }^{\circ} \mathrm{C}$ ) and a short hot vapor residence time $\sim 1 \mathrm{~s}$, resulting in condensable gases (bio-oil), non-condensable gases, and biochar. Gasification operates at higher temperatures (between 600 and $1200^{\circ} \mathrm{C}$ ) with a long vapor residence time, generating gaseous fuels [18]. However, pyrolysis has relatively low investment costs and high energy performance compared with other processes, especially on a small scale, and can potentially scale up to industrial level $[19,20]$. The purpose of a pyrolysis plant is often to produce one main product, either bio-oil or biochar, and thus, the process is often optimized for one product and the by-products are combusted to generate process heat [21]. Both the non-condensable gas and bio-oil can potentially be utilized for energy production, although in reality their utilization can be challenging and requires additional processing steps [22]. The biochar can be used as a soil amendment, as it usually contains $80-90 \%$ stable carbon that is resistant to decomposition and mineralization, and therefore can offer a direct method to sequester carbon for long periods [23, 24]. Furthermore, when used as a soil amendment, biochar can improve soil fertility, soil structure, nutrient availability, and soil water retention capacity $[25,26]$. Moreover, biochar can be used for energy purposes, due to its high energy content $[27,28]$.

Many studies examining the bioenergy production systems based on pyrolysis of short-rotation coppice willow have shown good performance in energetic and economic aspects [29-31], and short-rotation coppice willow is a lignocellulose-rich energy crop considered a renewable fuel in many countries [32-34]. It has a relatively fast growth rate and low agro-chemical requirement [35]. In Swedish energy policy discussions, the introduction of willow plantations for energy purposes has been suggested as an important alternative biomass source of woody fuel, produced on Swedish farmland [36]. The crop is commercially grown, mainly on agricultural land, and the biomass produced is used in district heating plants for combined heat and power (CHP) production. About 7800 ha of willow in short-rotation coppice systems is currently grown in southern and central Sweden [37]. Willow requires intensive site preparation and nutrient inputs. However, there are several characteristics that make it ideal for woody crop bioenergy systems, including high yields obtained in a few years (rotation 3-10 years), ease of vegetative propagation, a broad genetic base, a short breeding cycle, and the ability to re-sprout after multiple harvests. Willow also has a broad species diversity, which is important in the successful development of the crop and resistance to pests and diseases [38].

When novel conversion routes are used, it is important to assess the energetic and environmental performance of these from a systems perspective and compare it with that of conventional techniques. Life cycle assessment (LCA) is an internationally accepted methodology for calculating the environmental performance of products or services 
$[39,40]$. It provides a better understanding of how alternative systems compare to each other and also how different sub-processes in a system affect the overall results [41]. The LCA framework has been widely applied to evaluate the environmental impacts of products and to study the environmental impacts of biofuels (e.g., [42]). It has also been used to assess GHG emissions according to the European Union (EU) sustainability criteria [43, 44].

It is well known that some biofuel production processes require large primary energy inputs and also contribute high levels of GHG emissions (e.g., during biomass production, transport, fuel production technologies) $[45,46]$. Furthermore, land use change (LUC) can increase GHG emissions from biofuel production by affecting the carbon balance in the soil [47]. Land management practices can change the characteristics and gas exchange of an ecosystem dramatically. Additionally, assessing the changes in soil organic carbon (SOC) storage is an important factor in accurately estimating GHG emissions in bioenergy LCA [48]. Changes in SOC are directly related to the level of GHG emissions in an LCA study, while SOC itself is an important indicator of soil quality [49].

Since biomethane can potentially be supplied through pyrolysis of short-rotation coppice willow as an emerging technology, it is of interest to study the performance and compare it with the well-established AD of maize regarding the land use efficiency. The goal of this study was to assess and compare the energy performance and global warming potential (GWP) of biomethane production in a life cycle perspective when transitioning from a maize-based $\mathrm{AD}$ system producing biomethane to a short-rotation coppice willow on the same arable land and using a pyrolysis process to produce the biomethane. Continued production of biomethane using a maize-based $\mathrm{AD}$ system was used as the reference.

\section{Material and methods}

Life cycle assessment methodology [39, 40] was used to assess the energy performance and climate impact of two different biomethane production scenarios: a reference scenario in which maize was converted to biogas using AD and a willow scenario in which a methane-rich gas was produced by pyrolysis of short-rotation coppice willow. The willow scenario had two sub-scenarios, where (a) the biochar was returned to agricultural land and (b) the biochar was used as an energy source. In all scenarios, the gas was assumed to be upgraded $(97 \%$ $\mathrm{CH}_{4}$ ) for use as a vehicle fuel or injected to the gas grid, but the use phase of biomethane was not included in the analysis. An attributional approach was used to model the system and determine the inventory of physical flows between the environment and the technical system. Calculations were performed in Excel spreadsheets, using data on upstream emissions taken from Ecoinvent (version 3.3) and combined literature.

\section{System boundaries, functional units, and general assumptions}

The study period covered 44 years of maize and willow cultivation, i.e., 44 years of annual maize cultivation and two subsequent willow rotations spanning 22 years each. The agricultural land dedicated to biomethane production was assumed to be 2500 ha in southern Sweden that had previously been cropped with maize for biomethane production through AD. It was assumed that, in years prior to the study period, digestate was returned to the field as a nutrient supply for a prolonged period, bringing the SOC levels to reach a steady state before the study period.

Unit processes included within the system boundaries of the study were agricultural operations, road transport of biomass to the biomass conversion plant, operations in biomass conversion plants, and handling and transport of by-products (digestate/biochar) (Fig. 1). The biomass conversion plants (AD and pyrolysis plants) were assumed to be established within the local vicinity of the agricultural land, with an average transport distance of $24 \mathrm{~km}$ from the field to the biomethane production plant [50]. Based on [51], production of capital goods, such as machinery and buildings, was not included in the calculations due to substantially higher primary energy (PE) input and climate impact from other processes for biomethane production, such as agricultural operations.

The study was limited to the impact of the three major GHGs: $\mathrm{CO}_{2}$, nitrous oxide $\left(\mathrm{N}_{2} \mathrm{O}\right)$, and $\mathrm{CH}_{4}$, originating from biogenic sources and the technical system. All energy inputs and GHG emissions from each production unit in the life cycle in the two scenarios until after biomethane upgrading were included in the analysis. Delivery of the biomethane to the end users and end use were not included. The biogenic carbon incorporated in the final biomethane product was considered climateneutral, as it was intended for subsequent combustion. However, biomethane leakage during upgrading was accounted for.

Two different functional units (FU) were used: (1) a FU of hectares (ha) of land per year was used to enable comparison of relative land use efficiency of the system dedicated to energy crop cultivation for biomethane production and (2) a FU of energy content of the biomethane in the delivered product (GJ) was used in order to compare the energy service delivered by each system and enable comparison of biomethane output with its fossil-based counterparts. 


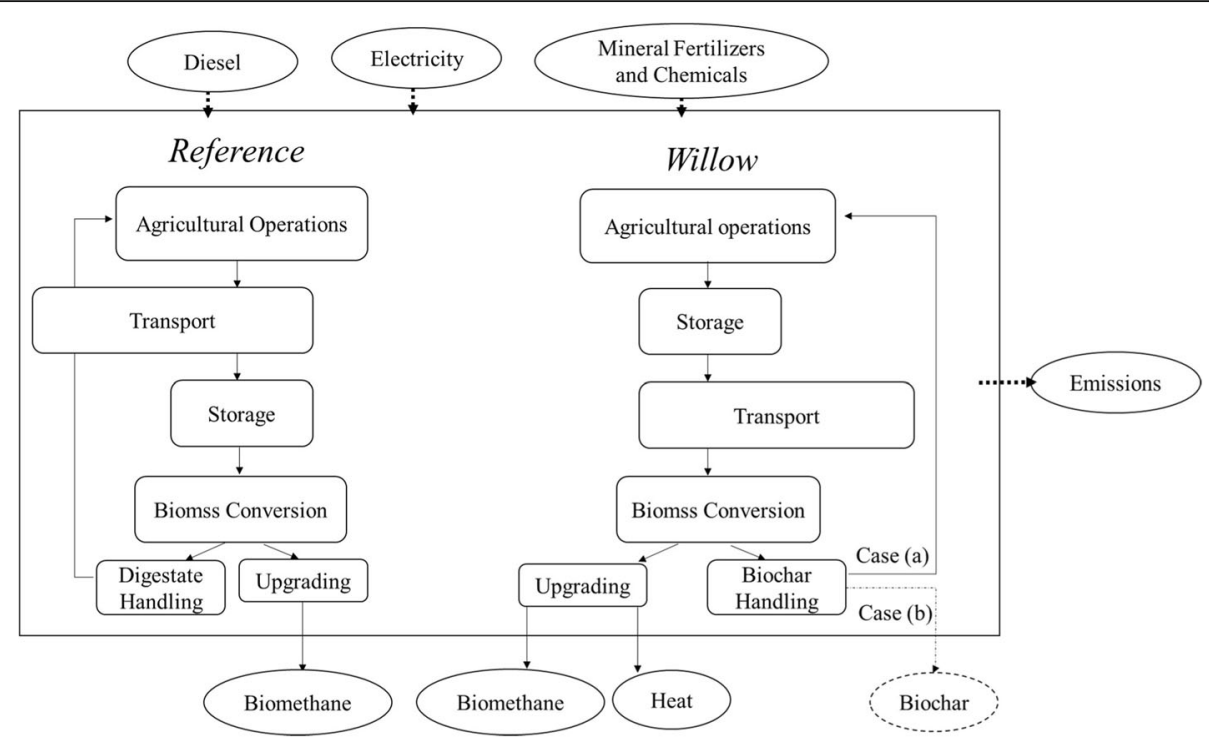

Fig. 1 System boundary of the study, including agriculture operations for biomass production (maize and willow), transport and storage, biomass conversion (anaerobic digestion (AD) and pyrolysis), and final gas upgrading along with by-product (digestate and biochar) handling operations. There were two willow scenarios: in willow scenario a, the biochar was returned to agricultural land, and in willow scenario b, the biochar was used as an energy source

\section{Allocation and system expansion}

Multi-functionality problems arise when one process generates more than one product, as was the case with the willow scenarios in this study. International Standardization Organization (ISO) standards recommend avoiding allocation in the first instance by increasing the level of detail in the study or by performing a system expansion. In a system expansion, the by-products are assumed to substitute existing products on the market and the environmental impacts from the substituted products are subtracted from the total impact of the system under study. However, multi-functionality can be handled by allocating the environmental impacts on all products, based, for example, on their physical or economic properties [39]. In this study, physical allocation and system expansion were both tested, to investigate the effect of different approaches on the outcome of the study (Fig. 2).

The allocation method was used for the default willow scenario (i.e., willow scenario a), in which the biochar was assumed to be returned to the soil as a soil amendment. The allocation was performed based on the lower heating value (LHV) of the biomethane and high-value excess heat. This is a common approach in LCA of biofuel systems $[52,53]$ and is also recommended by the EU regulations on biofuel GHG performance [54].

In willow scenario b, climate impact mitigation prospect was also quantified by considering complete substitution of fossil alternatives in a system expansion. The system expansion was performed by assuming (i) that the exported heat substituted heat from a natural gas-fed, large-scale CHP plant fitted with a gas turbine and a power-to-heat ratio of 0.45 with a total efficiency of $90 \%$ and (ii) that $1 \mathrm{Mg}$ of biochar substituted $3 \mathrm{Mg}$ of hard coal based on the LHV in industrial processes. In the system expansion approach, the distance between the conversion plant and end user of biochar was assumed to be the transport distance between the farm and plant. Data for the fossil-based products were sourced from the Ecoinvent database version 3.3 [55].

\section{System description}

\section{Reference scenario-maize $A D$}

Maize agricultural operations Maize cultivation was assumed to comprise land preparation, including deep plowing and harrowing of soil. Seeds were assumed to be treated with fungicide and insecticide before sowing during late spring [56]. Harvest was assumed to be in autumn, with an average yield of $13 \mathrm{Mg} \mathrm{DM} / \mathrm{ha}$ and a moisture concentration of 40\% [57]. In-field transport of $2 \mathrm{~km}$ was considered. The nutrient and chemical requirements of the maize cropping system are presented in Additional file 1: Tables S1 and S3.

Biological conversion and upgrading The biogas plant was assumed to process $32,500 \mathrm{Mg}$ DM maize silage annually, with a total feedstock energy content of $149 \mathrm{GWh}$, based on the LHV [58]. The digester process was assumed to be a batch digester with wet fermentation $(15 \% \mathrm{TS})$ under mesophilic $\left(30-37^{\circ} \mathrm{C}\right)$ conditions. The maize silage was assumed to be delivered to a hopper and mixer, where it was comminuted to a particle 


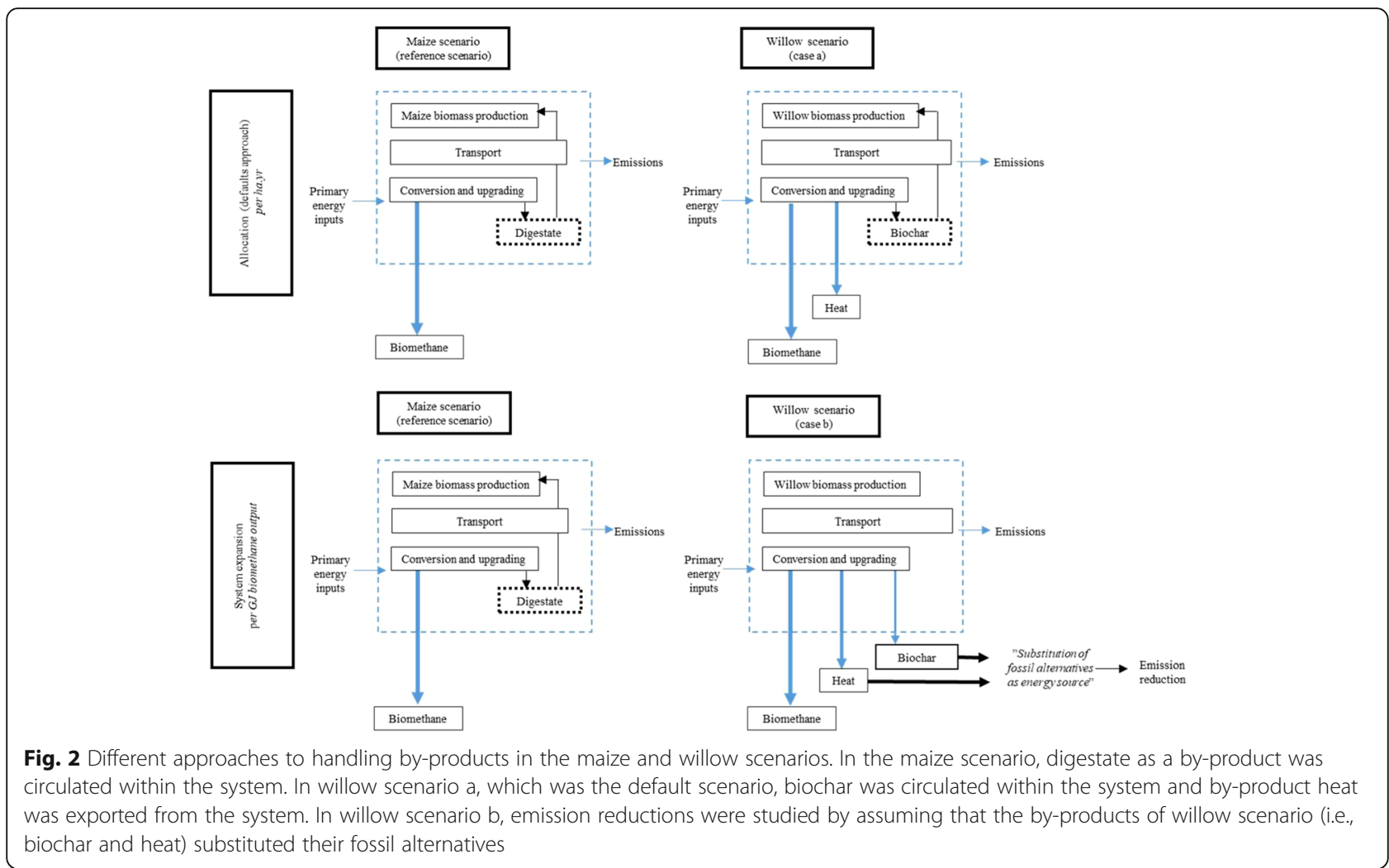

geometric length of $2 \mathrm{~mm}$. In order to obtain a viscosity suitable for the mixing equipment, a share of the liquid digestate leaving the digester, after solid-liquid separation, was assumed to be returned to the inlet mixing unit $[59,60]$. The feedstock then passed through a macerator before being pumped into the anaerobic digester. The total annual biomethane production corresponded to $102 \mathrm{GWh}$. The heat requirement of the digester was assumed to be met by burning part of the produced biogas (9.6\%). The electricity used for operating the $\mathrm{AD}$ plant was assumed to be taken from the grid. The raw biogas $\left(60 \% \mathrm{CH}_{4}\right)$ was upgraded in a water scrubber to vehicle fuel quality $\left(97 \% \mathrm{CH}_{4}\right)$ [58]. Outputs from the anaerobic digestion plant were biomethane and digestate (Fig. 3).

Digestate handling The AD plant assumed in this case had an annual digestate output of $65,000 \mathrm{Mg}$. All nutrients present in the feedstock of the maize $\mathrm{AD}$ scenario were assumed to end up in the digestate. The mineral nitrogen $(\min -\mathrm{N})$, total phosphorus (tot-P), and potassium $(\mathrm{K})$ content of the digestate were assumed to have the same fertilizer effect as mineral fertilizer. In the reference scenario, $86 \%, 89 \%$, and $60 \%$ of the required $\mathrm{N}, \mathrm{P}$, and $\mathrm{K}$, respectively, was supplied to the crop with the AD digestate, while the remaining nutrients were supplied using mineral NPK fertilizer [61] (Additional file 1: Table S1 and S3).
The digestate generated was assumed to be phase-separated using a screw press, resulting in a solid and a liquid digestate. The annual output of liquid and solid digestate was 58,500 and $6500 \mathrm{Mg}$, respectively. The liquid was stored in covered lagoons in order to reduce emissions of $\mathrm{CH}_{4}$ [62]. The solid fraction was assumed to be collected in containers and transported to farms, where it was stored in piles before being applied to soils using a broadcaster [52].

Road transport and storage The biomass was assumed to be transported for $24 \mathrm{~km}$ using a lorry with a maximum load of $60 \mathrm{Mg}$ wet weight (ww), assuming a fill rate of $100 \%$ on transport between the field and the biomethane production plant and an empty return trip. Maize used for biogas production was assumed to be ensiled during storage. Losses during ensiling were assumed to be compensated for by changes in the composition of fermentation products during ensiling, leading to unchanged methane yield from the maize silage [63].

\section{Willow scenario}

Willow agricultural operations The study period covered two subsequent willow rotations, spanning 22 years each, including 73-year coppicing cycles. To ensure a 


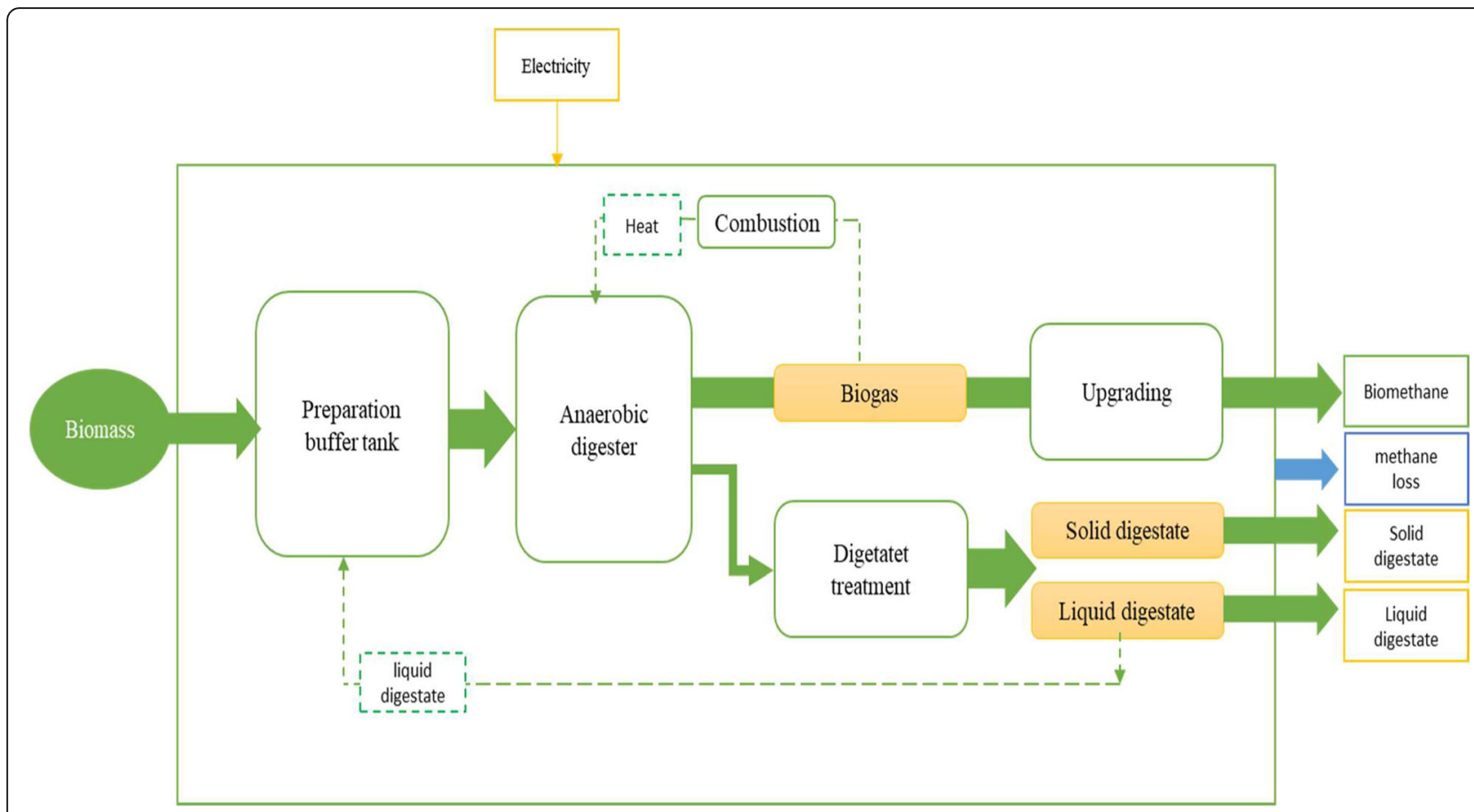

Fig. 3 Biomass conversion to biomethane in the reference maize-anaerobic digestion (AD) scenario. Different steps of biomass conversion to biomethane in an AD plant, including inputs (biomass and electricity) and outputs (biomethane, digestate, and methane losses). Digestate (i.e., solid and liquid digestates) was circulated within the system to the soil as a plant fertilizer

constant supply of willow to the pyrolysis process, one third of the total area needed was assumed to be established each year over a period of 3 years. The biomass yield in the first harvest of each rotation yielded $20 \mathrm{Mg}$ $\mathrm{DM} / \mathrm{ha}$, while in the second to sixth harvest yield was 30 $\mathrm{Mg} \mathrm{DM} / \mathrm{ha}$. Mean annual growth rate over an entire rotation was set at $9 \mathrm{Mg} \mathrm{DM} / \mathrm{ha} /$ year with an average moisture concentration of 48\% [64]. Field operations started with plowing before planting the seedlings. Fertilization was assumed to be performed in the first year after establishing the willow. Weed control, both mechanical and chemical, was assumed. Herbicides were applied prior to plowing and during the establishment year. The nutrient and chemical requirements of the willow cropping system are presented in Additional file 1: Tables S2 and S3. Harvesting was assumed to take place in winter, using a whole stem harvester [65]. The roots and stools were assumed to be removed in spring after the final harvest of each rotation, and the soil was then prepared for a new rotation in the following spring by repeating the field operations of the first rotation. Establishment guidelines for willow were based on [66].

Thermochemical conversion and upgrading The pyrolysis plant was assumed to process $22,500 \mathrm{Mg}$ DM of willow annually, corresponding to $113 \mathrm{GWh}$ based on the LHV of the feedstock. The energy and material flows for the pyrolysis process were based on a process simulation in Aspen Plus ${ }^{\odot}$ [29], which included pre-treatment of biomass, pyrolysis of biomass, and fuel synthesis (i.e., pre-reforming and methanation). The final gas was upgraded to biomethane $\left(97 \% \mathrm{CH}_{4}\right)$. Outputs from the pyrolysis plant were biomethane, biochar, and exported heat (Fig. 4).

In the pre-treatment step, the biomass was assumed to be dried to a moisture content of $7 \%$. The feedstock was then reduced in size (to $3 \mathrm{~mm}$ ) using an electric grinder, in order to ensure a high heating rate in the pyrolysis process.

The pyrolysis of biomass was assumed to take place in a bubbling fluidized bed reactor with external heating and vapor recirculation. The heat of pyrolysis was supplied by burning $12 \%$ of the total biomass input [29]. The pyrolysis gas was cleared of solid particles and sulfur by adsorption filters [67], to avoid catalyst poisoning and deactivation. Then, part of the pyrolysis gas was recycled, compressed, and injected into the pyrolysis reactor to fluidize the pyrolysis reactor bed. The recycled pyrolysis gas was extracted after the filtering to protect the downstream equipment. The biochar was collected from the pyrolysis reactor and quenched.

The pyrolysis gas from the reactor was then assumed to be converted to biomethane in a fuel synthesis step. In the pre-reforming step, long hydrocarbon chains were converted into mainly $\mathrm{CO}_{2}$, carbon monoxide $(\mathrm{CO})$, $\mathrm{CH}_{4}$, and hydrogen gas $\left(\mathrm{H}_{2}\right)$ in the presence of a nickel 


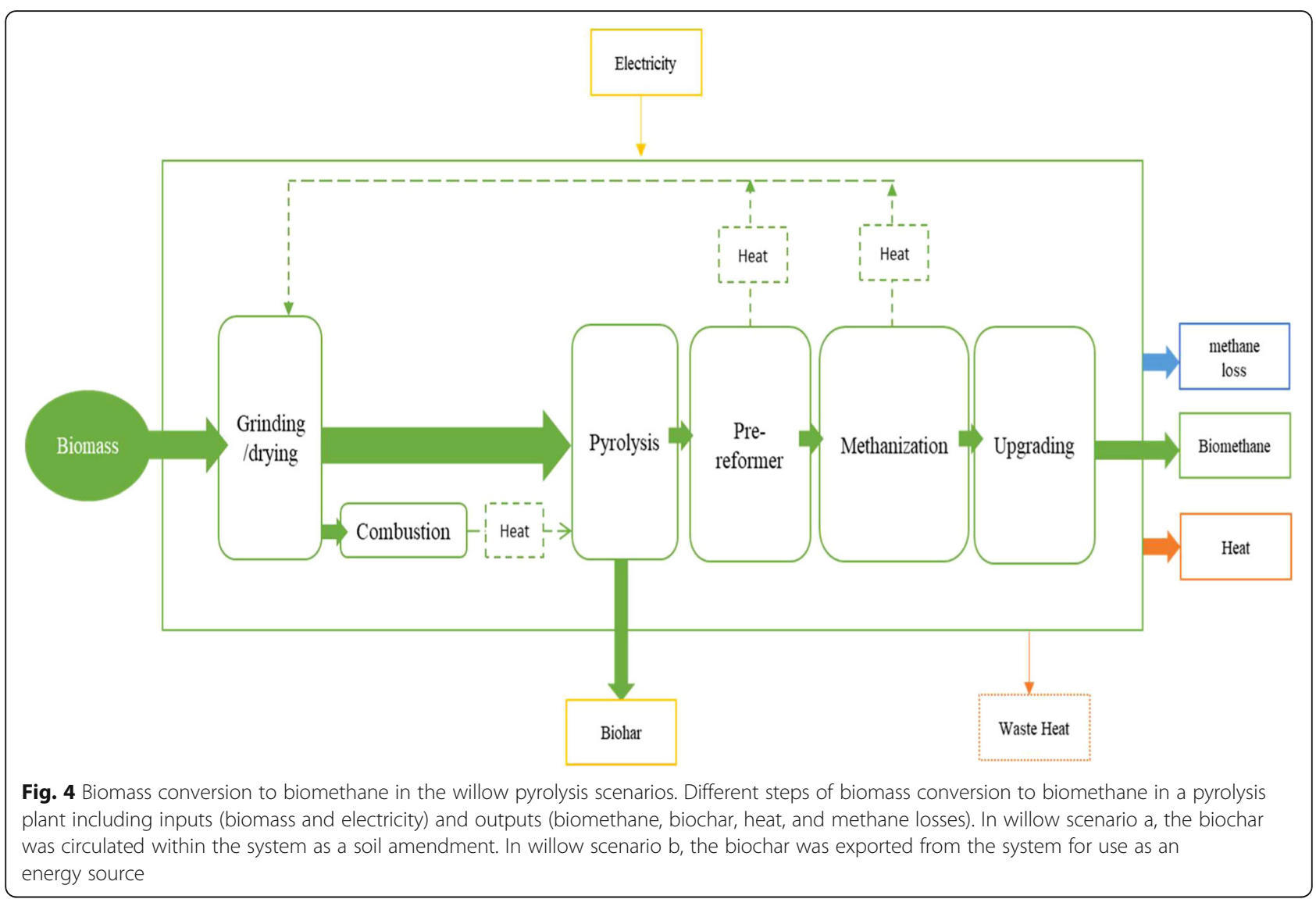

catalyst (at $500{ }^{\circ} \mathrm{C}$, atmospheric pressure) in an adiabatic fixed bed reactor. This was assumed to be followed by a combined water-gas shift (Eqs. 1 and 2) and a methanation reaction (Eq. 3), where $\mathrm{CO}$ and $\mathrm{H}_{2}$ were converted to $\mathrm{CH}_{4}$ in the presence of a nickel catalyst (at $300^{\circ} \mathrm{C}$ and 10 bars) in an isothermal reactor. Water molecules served as a source of hydrogen in the water-gas shift reaction and also to prevent carbon deposition on the catalyst in the pre-reformer and methanation reactor by lowering the partial pressure for carbon. The $\mathrm{H}_{2} \mathrm{O} / \mathrm{C}$ ratio was $1: 1$ on a mole basis, which is considered sufficient to minimize carbon deposition [29].

$$
\begin{aligned}
& \mathrm{CO}+\mathrm{H}_{2} \mathrm{O} \rightleftarrows \mathrm{CO}_{2}+\mathrm{H}_{2} \\
& \mathrm{CO}+3 \mathrm{H}_{2} \rightarrow \mathrm{CH}_{4}+\mathrm{H}_{2} \mathrm{O} \\
& \mathrm{CO}_{2}+4 \mathrm{H}_{2} \rightarrow \mathrm{CH}_{4}+2 \mathrm{H}_{2} \mathrm{O}
\end{aligned}
$$

After the fuel synthesis, the gas contained mostly $\mathrm{CH}_{4}$, $\mathrm{CO}_{2}, \mathrm{H}_{2} \mathrm{O}$, and traces of $\mathrm{CO}$ and $\mathrm{H}_{2}$. A water scrubber was assumed to be used to upgrade the gas to meet vehicle fuel quality $\left(97 \% \mathrm{CH}_{4}\right)$. Details of the heat and energy balance of the pyrolysis process reactions and upgrading step are given in Additional file 1: Figure S1 and Table S4.

There was a substantial production of heat in the willow scenarios. The heat generated in the reformer and methanation step was assumed to be used internally for drying the biomass $(0.62 \mathrm{MW})$ in the pre-treatment step, with part of the heat lost through the reactor walls as waste heat, while the exported heat $\left(>300^{\circ} \mathrm{C}\right)$ was assumed to be used in other industries.

Biochar handling The default case in the study comprised willow scenario a, where the biochar was assumed to be applied to the soil of an annual crop plantation, slowly mineralize through physical and chemical processes, returning carbon to the atmosphere. The biochar was assumed to be applied with manure shortly before tilling or disking operations, requiring no extra operations for incorporation. Emission data for the biochar handling and soil application are presented in Additional file 1: Table S2.

Road transport and storage The stems were assumed to be cut and then stored in bundles near the field for natural drying. During storage, the moisture content was assumed to be reduced to $20 \% \mathrm{WC}$, resulting in an increased net calorific value. Dry matter losses were 
assumed to be $0.3 \mathrm{Mg} / \mathrm{ha} /$ year during the first 6 months after harvest [68]. The dry stems were assumed to be transported by a truck loaded up to $20 \mathrm{Mg}$ DM to the pyrolysis conversion plant, with the truck making an empty return trip back to the field.

\section{Inventory calculations and impact assessment Primary energy input and energy ratio}

The PE included in calculations was the external energy inputs crossing the system boundary, such as energy for raw material production, agricultural operations, transportation of biomass and by-products, and conversion of biomass to biomethane. The use of internally generated energy and energy in the biomass feedstock itself (i.e., heat recirculation, burning part of the biomass/biogas as process fuel in the fuel production plants) was not included as an energy input. However, upstream PE inputs (e.g., extraction of fossil fuels, conversion, transmission, and distribution losses) were included [69]. Factors used for the conversion of data on electricity and of diesel to PE are presented in Table 1.

The external energy ratio (ER) [70] was used as an indicator of the energy performance of the two systems. The ER was defined as the energy content of the biomethane delivered relative to the total PE inputs (Eq. 4):

$$
\mathrm{ER}=\frac{\text { Delivered energy }}{\text { Total PE input }}
$$

\section{Greenhouse gas emissions and climate impact assessment}

The GWP was calculated based on the net emissions of each GHG over the entire study period, using a time horizon of 100 years $\left(\mathrm{GWP}_{100}\right)$. The characterization factors used when calculating the $\mathrm{GWP}_{100}$ were 28 and 30 for biogenic and fossil $\mathrm{CH}_{4}$, respectively, and 265 for $\mathrm{N}_{2} \mathrm{O}$ [71].

Biogenic carbon fluxes In the willow scenarios, maize cultivation was replaced by short-rotation coppice willow, causing SOC stock changes over the course of the study period. These SOC changes affected the GHG flows in willow scenarios a and b. In willow scenario a, the application of biochar to the soil also affected the GHG flows. The $\mathrm{CO}_{2}$ fluxes between the atmosphere and the biosphere were modeled using the i ntroductory carbon balance model (ICBM) [72] and were included in the assessment of the climate impact (Additional file 1: Appendix S5). The biosphere was divided into three different pools: soil organic carbon (SOC), digestate, and biochar (Fig. 5). In each of these, the difference in carbon stocks between the start and the end of the study period was calculated using different models.

\section{SOC modeling}

The change in SOC stocks between the beginning and the end of the study period was calculated using the ICBM model (Additional file 1: Appendix S5) [72], a soil carbon model for studying the soil carbon dynamics of agricultural land. The biogenic $\mathrm{CO}_{2}$ fluxes between the atmosphere and carbon stocks in soil were modeled based on estimations, allocation patterns, and carbon balance models adapted from [73]. All biogenic C fluxes to the atmosphere from the different pools were assumed to be in the form of $\mathrm{CO}_{2}$. The initial SOC stock (previous land use) was calculated by performing a spin-up simulation of 1000 years based on the carbon input in the reference scenario. The initial SOC level was set at $130 \mathrm{Mg} \mathrm{C} / \mathrm{ha}$ in both scenarios. The digestate applied to the soil was considered an input with relevance for the SOC calculations. It was assumed that $26 \mathrm{Mg} / \mathrm{ha} /$ year of digestate with a total carbon content of $15 \%$ was applied to the land in the reference scenario. The data used in the SOC calculations are presented in Additional file 1: Appendix S5.

\section{Biochar stock modeling}

In willow scenario a, biochar was assumed to be applied to the soil in the willow plantation. An exponential decay model was used to model the biochar stock change between the first and last year of the study period, based on a model by Zimmerman [74]. It was assumed that $1 \mathrm{Mg} / \mathrm{ha} /$ year of biochar with a total carbon content of $76.1 \%$, pyrolyzed at $550^{\circ} \mathrm{C}$, was applied to the land. A description of the biochar decay model used in this study can be found in Additional file 1: Appendix S6.

\section{Emissions from technical systems and fertilization- induced emissions Emissions from the technical system related to agricultural operations were based on the life cycle emissions of the energy carriers and chemicals used (Additional file 1: Table S3). In the reference scenario, $\mathrm{CH}_{4}$ emissions from the $\mathrm{AD}$ unit of the biogas production were set to $1 \%$ of the biomethane produced [75]. No methane}

Table 1 Primary energy (PE) factor (defined as the ratio between PE and delivered useful energy) and greenhouse gas (GHG) emissions factors for different energy carriers [55]

\begin{tabular}{|c|c|c|c|}
\hline Energy carrier & Specification & PE factor (MJ-eq./MJ) & Emission ( $\mathrm{g} \mathrm{CO}_{2}$-eq./MJ) \\
\hline \multirow[t]{2}{*}{ Electricity } & Nordic electricity mix (NORDEL) & 2.01 & 20 \\
\hline & Hard coal NORDEL & 3.24 & 292 \\
\hline Fuel & Diesel, low-sulfur & 1.35 & 0.01 \\
\hline
\end{tabular}




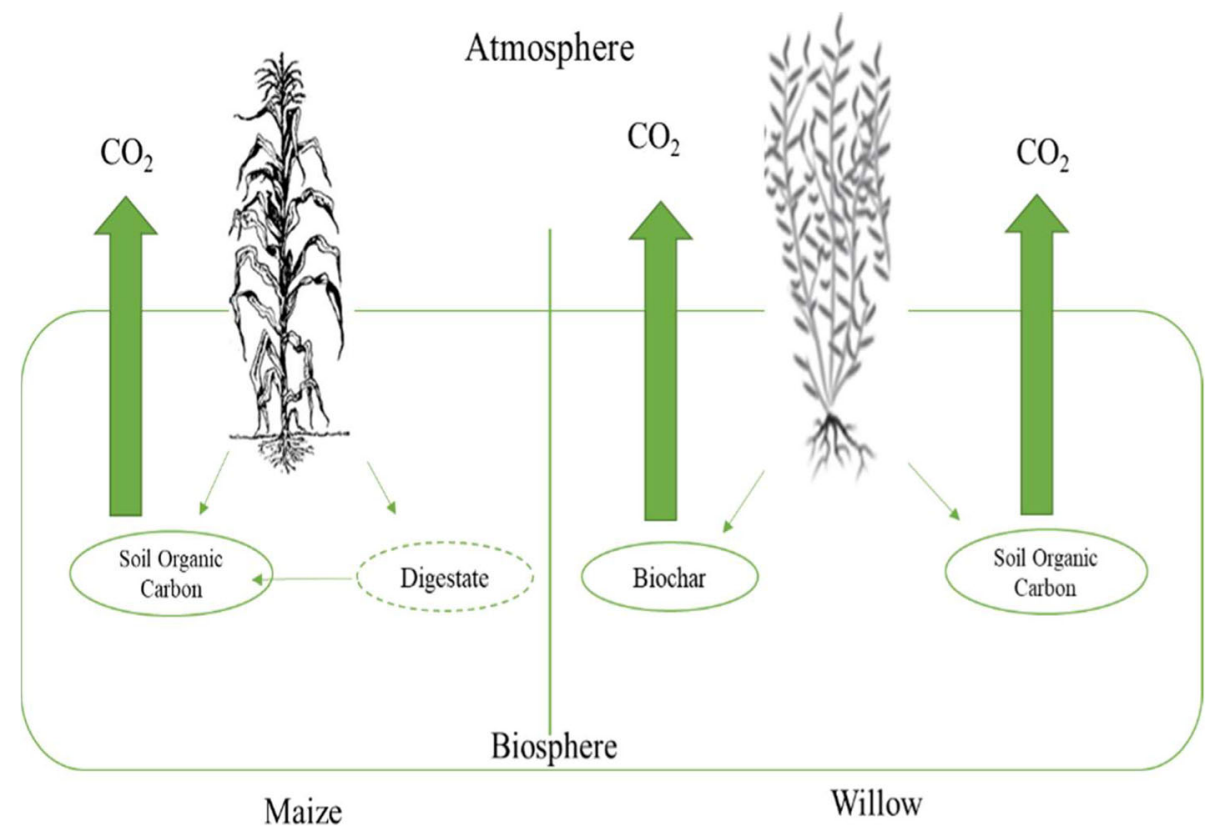

Fig. 5 Biosphere pools in the reference (maize) scenario and in willow scenario a. Carbon dioxide $\left(\mathrm{CO}_{2}\right)$ fluxes between the atmosphere and biosphere and carbon (C) fluxes between the different pools in the biosphere included in the modeling

emissions were assumed from the pyrolysis process unit. Methane loss during the upgrading of gases within the two scenarios was set to $1 \%$ of the biomethane produced [76]. Methane emissions from the solid digestate storage contributed $0.7 \%$ of the biomethane produced [77].

Direct emissions of $\mathrm{N}_{2} \mathrm{O}$ from both fertilizers and digestate were included, assuming that $1 \%$ of the nitrogen applied was converted to $\mathrm{N}_{2} \mathrm{O}$. Indirect emissions were calculated assuming that $30 \%$ of the nitrogen applied was leached and that $0.75 \%$ of this leached fraction was subsequently converted to $\mathrm{N}_{2} \mathrm{O}$ [78].

\section{Results}

This section presents the energy performance and climate impact results for the different scenarios described in Fig. 1. The "Energy analysis" and "Greenhouse gas emissions and climate impact" sections compare willow scenario a with the maize AD reference scenario. The "Substitution of fossil alternatives" section presents the results regarding system expansion in willow scenario b, using biochar for energy purposes, compared with willow scenario a, using biochar as a soil amendment and the maize AD reference.

\section{Energy analysis \\ Outputs and energy ratio}

The energy inputs and outputs and energy ratio of the two biomethane production scenarios are presented in Table 2. Willow scenario a had twice as high energy ratio as the reference scenario, due to the relatively low external PE input, whereas the energy ratio for the reference scenario was lower due to the higher external PE input in relation to the biomethane output.

The output consisted of biomethane as the main product from both scenarios and exported heat as a by-product from willow pyrolysis. The net biomethane output for the reference scenario and willow scenario a was 141.0 and $111.0 \mathrm{GJ} / \mathrm{ha} /$ year, respectively. Willow scenario a exported $10 \mathrm{GJ} / \mathrm{ha} /$ year of heat that was of sufficient quality to be sold for use in other processes, such as steam production or district heating $\left(>300^{\circ} \mathrm{C}\right)$. In willow scenario a, a total of $21.7 \mathrm{GJ} / \mathrm{ha} /$ year was lost

Table 2 Primary energy (PE) inputs, outputs, losses, and energy ratio for the two biomethane production scenarios

\begin{tabular}{|c|c|c|c|c|c|c|c|}
\hline & Input (PE) & \multicolumn{3}{|l|}{ Output } & \multicolumn{2}{|l|}{ Losses } & \multirow{3}{*}{$\begin{array}{l}\text { Energy } \\
\text { ratio } \\
\text { (out/in) }\end{array}$} \\
\hline & \multicolumn{6}{|l|}{ (GJ/ha/year) } & \\
\hline & Total & Biomethane $^{1}$ & Exported heat & Total & Methane & Waste heat & \\
\hline Reference & 26.0 & 141.0 & 0.0 & 141.0 & 6.0 & 0 & 5.4 \\
\hline Willow a & 12.5 & 111.0 & 10.0 & 121.0 & 2.0 & 21.7 & 8.9 \\
\hline
\end{tabular}

${ }^{1}$ Biomethane lower heating value $=48 \mathrm{MJ} / \mathrm{kg}$ 
as waste heat. Methane losses from the reference scenario and willow scenario a corresponded to 6.0 and $2.0 \mathrm{GJ} / \mathrm{ha} /$ year, respectively.

The reference scenario required $15 \mathrm{GJ} / \mathrm{ha} /$ year for heating the digester, which was supplied internally by burning part of the biogas produced. In willow scenario a, the feedstock drying unit required $22 \mathrm{GJ} / \mathrm{ha} /$ year of heat, which was supplied internally from the final gas cooling stage. The pyrolysis reactor had a heat requirement of $21.0 \mathrm{GJ} / \mathrm{ha}$ /year, which was supplied by burning a fraction of the biomass.

\section{PE input}

The total PE inputs to the reference scenario and willow scenario a were 26.0 and $12.5 \mathrm{GJ} / \mathrm{ha}$ /year, respectively. The main PE input in the reference scenario was electricity use for the AD plant ( $9.6 \mathrm{GJ} / \mathrm{ha} /$ year). Electricity use for the upgrading of raw biogas $(8.1 \mathrm{GJ} / \mathrm{ha} /$ year) was related to the high pressure used in the water scrubber, resulting in increased solubility of $\mathrm{CO}_{2}$ in water [79]. Agricultural operations in the reference scenario required a total PE input of $4.8 \mathrm{GJ} / \mathrm{ha} / \mathrm{year}$, mainly as diesel in agriculture machinery (3.5 GJ/ha/year), fertilizer $(1.0 \mathrm{GJ} / \mathrm{ha} /$ year), and use of chemicals $(0.3 \mathrm{GJ} / \mathrm{ha} /$ year). Road transport of the maize feedstock to the AD plant and of the digestate back to the field had a total PE input of $2.5 \mathrm{GJ} / \mathrm{ha} /$ year. Digestate handling, corresponding to $26.0 \mathrm{Mg} \mathrm{ww} / \mathrm{ha} / \mathrm{year}$, required a total $\mathrm{PE}$ input of
$1.0 \mathrm{GJ} / \mathrm{ha} /$ year, as electricity use $(0.5 \mathrm{GJ} / \mathrm{ha} /$ year $)$ for pumping, stirring, and screw pressing of the digestate and as diesel use $(0.5 \mathrm{GJ} / \mathrm{ha} /$ year $)$ for field spreading of digestate by agricultural machinery (Fig. 6).

The main PE inputs to willow scenario a were electricity use in the biomass conversion unit of the pyrolysis plant (5.7 GJ/ha/year) and electricity use in the upgrading unit (1.0 GJ/ha/year). Agricultural operations in willow scenario a required a total PE input of $4.6 \mathrm{GJ} / \mathrm{ha} /$ year, including diesel consumption by agricultural machinery (2.5 GJ/ha/year), fertilizer production (2.0 GJ/ha/year), and use of chemicals $(0.1 \mathrm{GJ} / \mathrm{ha} /$ year $)$. Road transport of the willow feedstock to the pyrolysis plant and of the biochar back to the field had a total PE input of $0.7 \mathrm{GJ} / \mathrm{ha} /$ year. Biochar handling, corresponding to 1 $\mathrm{Mg}$ ww/ha/year, required $0.3 \mathrm{GJ} /$ ha/year electricity use in quenching equipment (Fig. 6).

Primary energy inputs per GJ biomethane output for the different processes in the reference scenario and willow scenario a are presented in Fig. 7. Willow scenario a generated biomethane and heat. The allocation factors were based on the LHV of output products, which was calculated to be $92 \%$ for biomethane and $8 \%$ for heat. The total $\mathrm{PE}$ input to the reference scenario and willow scenario a was 0.18 and $0.10 \mathrm{GJ} / \mathrm{GJ}$ biomethane output, respectively. In the reference scenario, the biomass conversion unit made the greatest contribution $(0.07 \mathrm{GJ} / \mathrm{GJ})$, followed by the upgrading of biogas $(0.06 \mathrm{GJ} / \mathrm{GJ})$. In willow scenario a, the biomass conversion unit $(0.05 \mathrm{GJ} / \mathrm{GJ})$ and agricultural

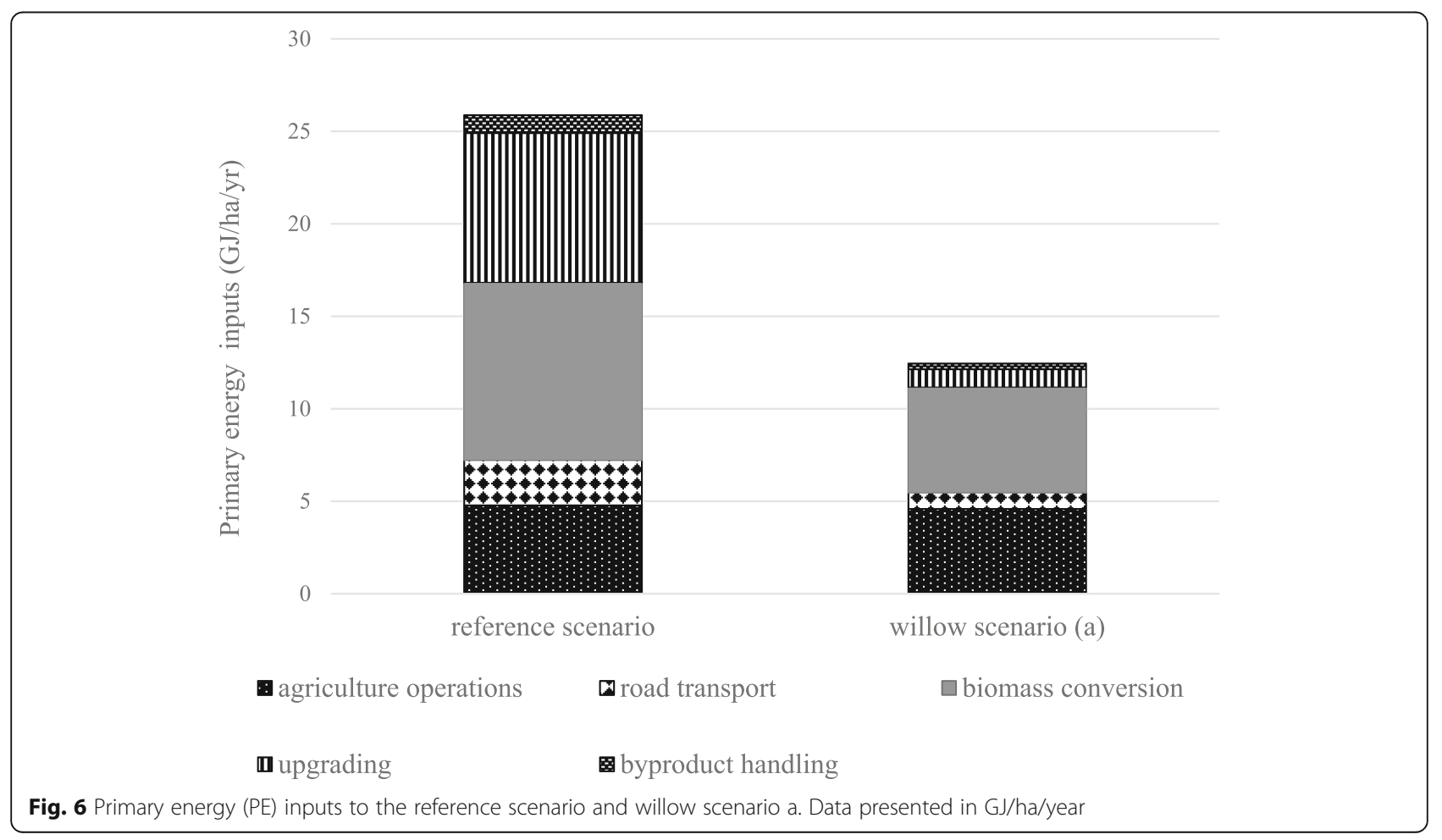




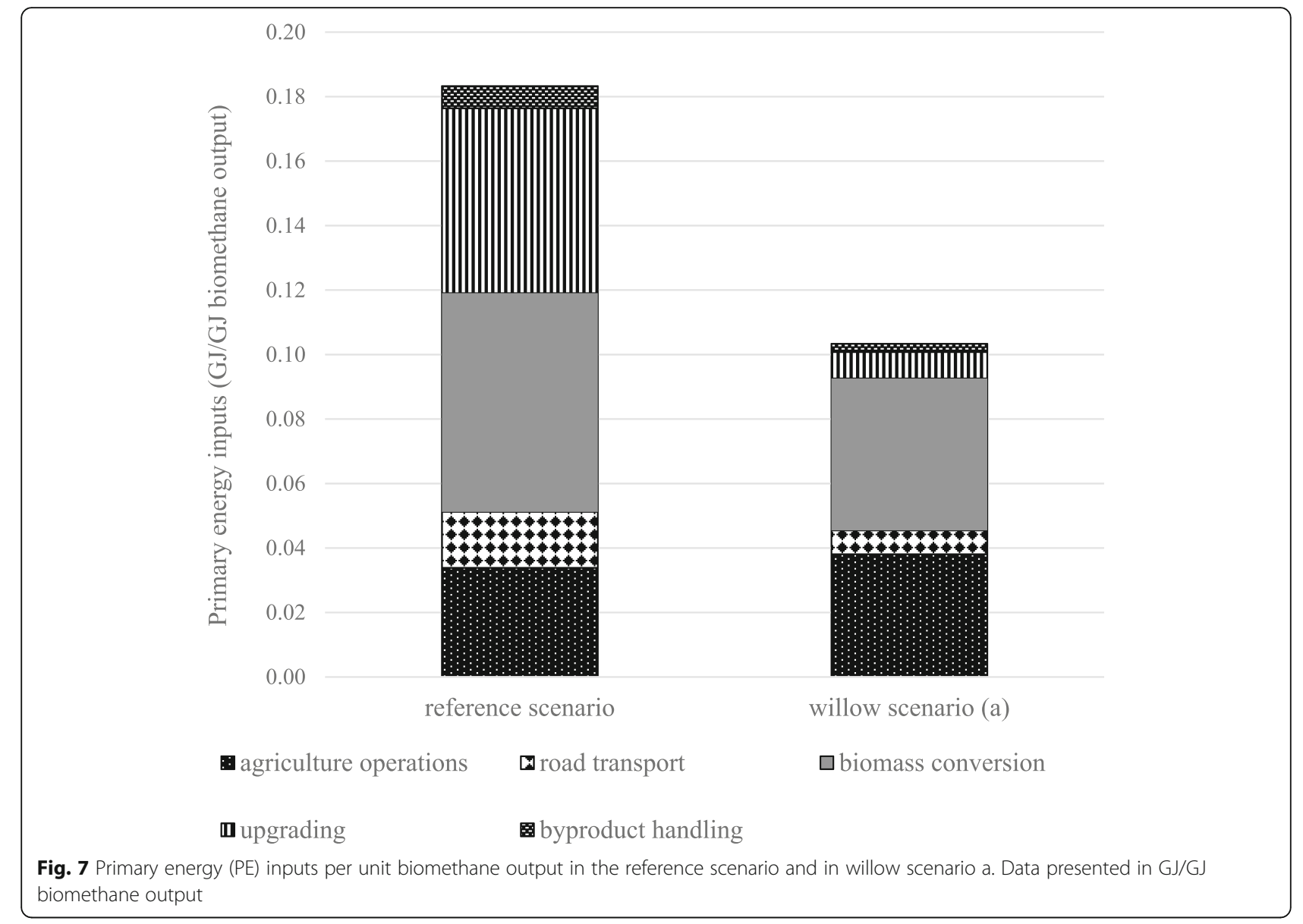

operations $(0.04 \mathrm{GJ} / \mathrm{GJ})$ made the greatest contribution to PE use per unit biomethane output (GJ).

\section{Greenhouse gas emissions and climate impact GHG emissions from technical systems and fertilization- induced emissions}

The total climate impact from the reference scenario was $4.6 \mathrm{Mg} \mathrm{CO}$-eq./ha/year. Willow scenario a had a net negative effect on the climate impact $(-0.5 \mathrm{Mg}$ $\mathrm{CO}_{2}$-eq./ha/year) (Fig. 8). In the reference scenario, the largest contributor to the climate impact was $\mathrm{AD}$, contributing $1.5 \mathrm{Mg} \mathrm{CO}$-eq./ha/year, which was related to direct methane losses $\left(1.3 \mathrm{Mg} \mathrm{CO}_{2}\right.$-eq./ha/year) and upstream emissions from electricity use in the $\mathrm{AD}$ unit (0.2 $\mathrm{Mg} \mathrm{CO}$-eq./ha/year). Agricultural operations and the upgrading unit had a similar climate impact, 1.2 and $1.1 \mathrm{Mg} \mathrm{CO}$-eq./ha/year, respectively. The main GHG emissions related to agricultural operations were fertilizer use $\left(0.9 \mathrm{Mg} \mathrm{CO} \mathrm{CO}_{2}\right.$-eq./ha/year $)$ and downstream emissions of diesel use in agricultural machinery (0.3 $\mathrm{Mg} \mathrm{CO}_{2}$-eq./ha/year). Direct $\mathrm{N}_{2} \mathrm{O}$ emissions from the soil due to fertilizer and digestate application in the reference scenario were 0.08 and $0.05 \mathrm{Mg}$ $\mathrm{CO}_{2}$-eq./ha/year, respectively. Methane losses in the upgrading unit were $0.8 \mathrm{Mg} \mathrm{CO}_{2}$-eq./ha/year and the upstream emissions from electricity use in the upgrading unit were $0.2 \mathrm{Mg} \mathrm{CO}_{2}$-eq./ha/year. The major GHG emissions in digestate handling were related to methane losses during open storage of solid digestate $(0.5 \mathrm{Mg}$ $\mathrm{CO}_{2}$-eq./ha/year) and storage of liquid digestate in lagoons (0.1 Mg CO 2 -eq./ha/year) (Fig. 8 ).

The main contributors to the climate impact in willow scenario a were fertilizer use and the biomass conversion unit, contributing 0.7 and $0.2 \mathrm{Mg} \mathrm{CO}_{2}$-eq./ha/year, respectively. The highest impact from the fertilizer unit was related to direct $\mathrm{N}_{2} \mathrm{O}$ emissions from the soil due to fertilizer application ( $0.5 \mathrm{Mg} \mathrm{CO}_{2}$-eq./ha/year). Major GHG emissions in biomass production were related to upstream emissions of electricity use $(0.11 \mathrm{Mg} \mathrm{CO}$-eq./ha/year). Direct methane emissions from the upgrading unit contributed $0.2 \mathrm{Mg} \mathrm{CO}_{2}$-eq./ha/year (Fig. 8).

\section{SOC and biochar}

There were no SOC stock changes in the soil in the reference scenario, since the SOC was assumed to have reached a steady state before the start of the study period. The climate impact in willow scenario a due to SOC stock changes when switching land use from maize 


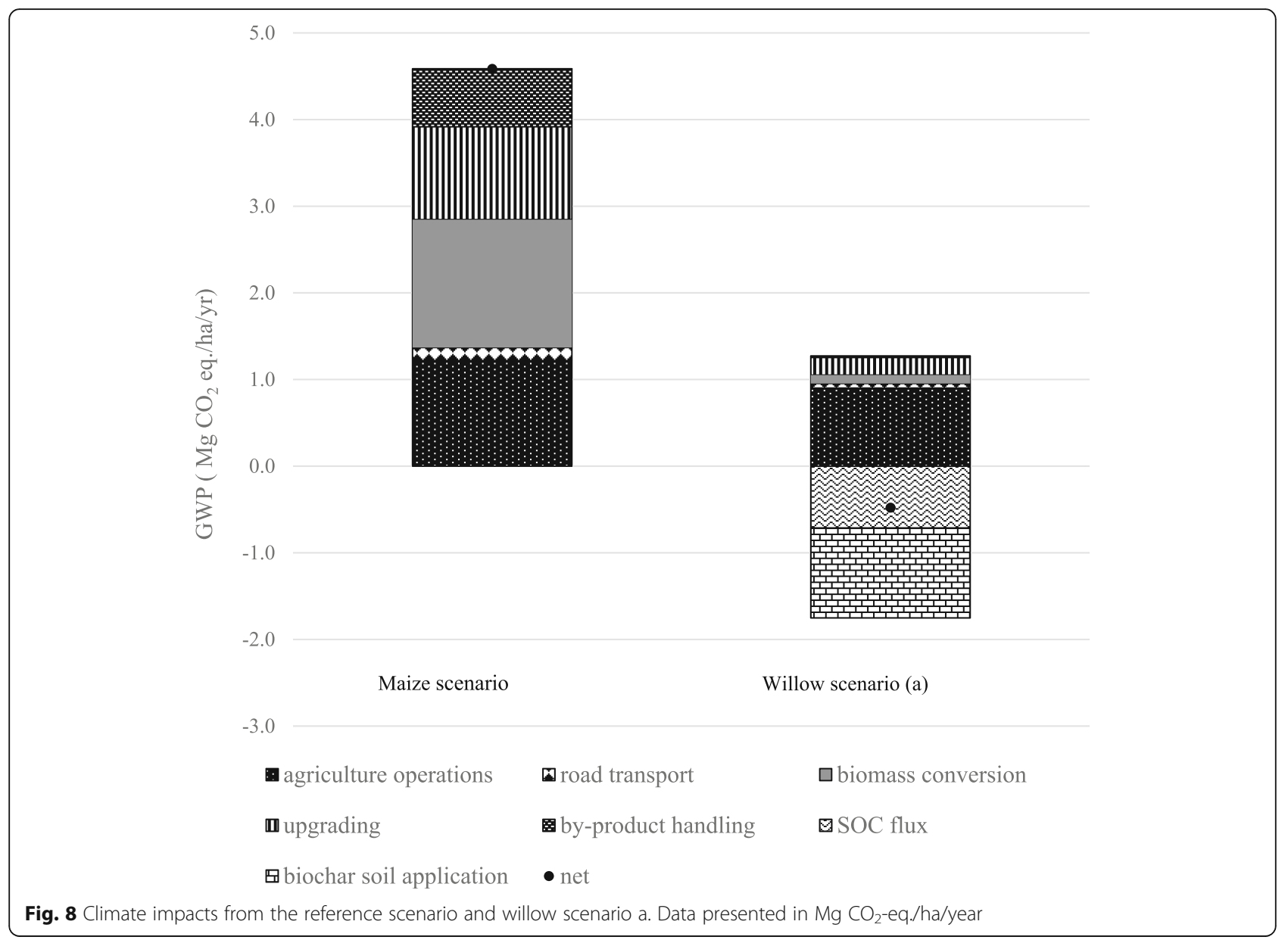

to willow was $-0.7 \mathrm{MgCO}_{2}$-eq./ha/year. The carbon sequestered in the biochar applied to the soil contributed an additional - $1.0 \mathrm{Mg} \mathrm{CO}_{2}$-eq./ha/year (Fig. 8).

\section{Substitution of fossil alternatives}

The climate impact for the equivalent amount of natural gas compared with the biomethane produced in the reference scenario and two willow scenarios a and b is shown in Fig. 9. Emissions for the natural gas relate to the production, distribution, and combustion of natural gas. Comparing the scenarios based on the FU of GJ biomethane output revealed that the reference scenario $(0.030 \mathrm{Mg} \mathrm{CO}$-eq/GJ biomethane) showed good performance in terms of climate impact in comparison with a natural gas-based scenario $\left(0.100 \mathrm{Mg} \mathrm{CO}_{2}\right.$-eq/GJ biomethane). However, better performance was obtained in willow scenario a (-0.004 $\mathrm{Mg} \mathrm{CO}_{2}$-eq./GJ biomethane), in which biochar was assumed to act as a soil amendment (Fig. 9). In willow scenario b, it was assumed that the exported heat substituted an equal amount of heat produced from a CHP using natural gas and that the biochar substituted $3 \mathrm{Mg}$ of fossil coal used as an energy source. The net climate impact of willow scenario b was
- $0.026 \mathrm{Mg} \mathrm{CO}_{2}$-eq./GJ biomethane. The exported heat from willow pyrolysis could thus potentially substitute $0.1 \mathrm{GJ}$ of fossil-based heat per GJ of biomethane output, reducing the climate impact by $0.006 \mathrm{Mg} \mathrm{CO}_{2}$-eq./ha/year (Fig. 9). Alternative use of biochar for energy could substitute $0.3 \mathrm{GJ}$ of hard coal per GJ of biomethane output and reduce the climate impact by $0.02 \mathrm{Mg} \mathrm{CO}$-eq./GJ biomethane. Thus, in the case considered in this study, the use of the biochar as an energy source and accounting for its replacement of fossil coal resulted in a lower climate impact than the use of the biochar as a soil amendment.

\section{Sensitivity analysis}

In studies assessing different scenarios, it is important to determine the impact of uncertainties and assumptions on the results and their interpretation. In this study, a sensitivity analysis was performed to evaluate the influence of changing the electricity mix, methane emissions from the upgrading step, and the yield of maize and willow on the results from the different scenarios (Figs. 10 and 11).

In the base case, an electricity mix for the Nordic countries (NORDEL) was used in the calculations. This was changed to electricity based on hard coal in the 
0.12

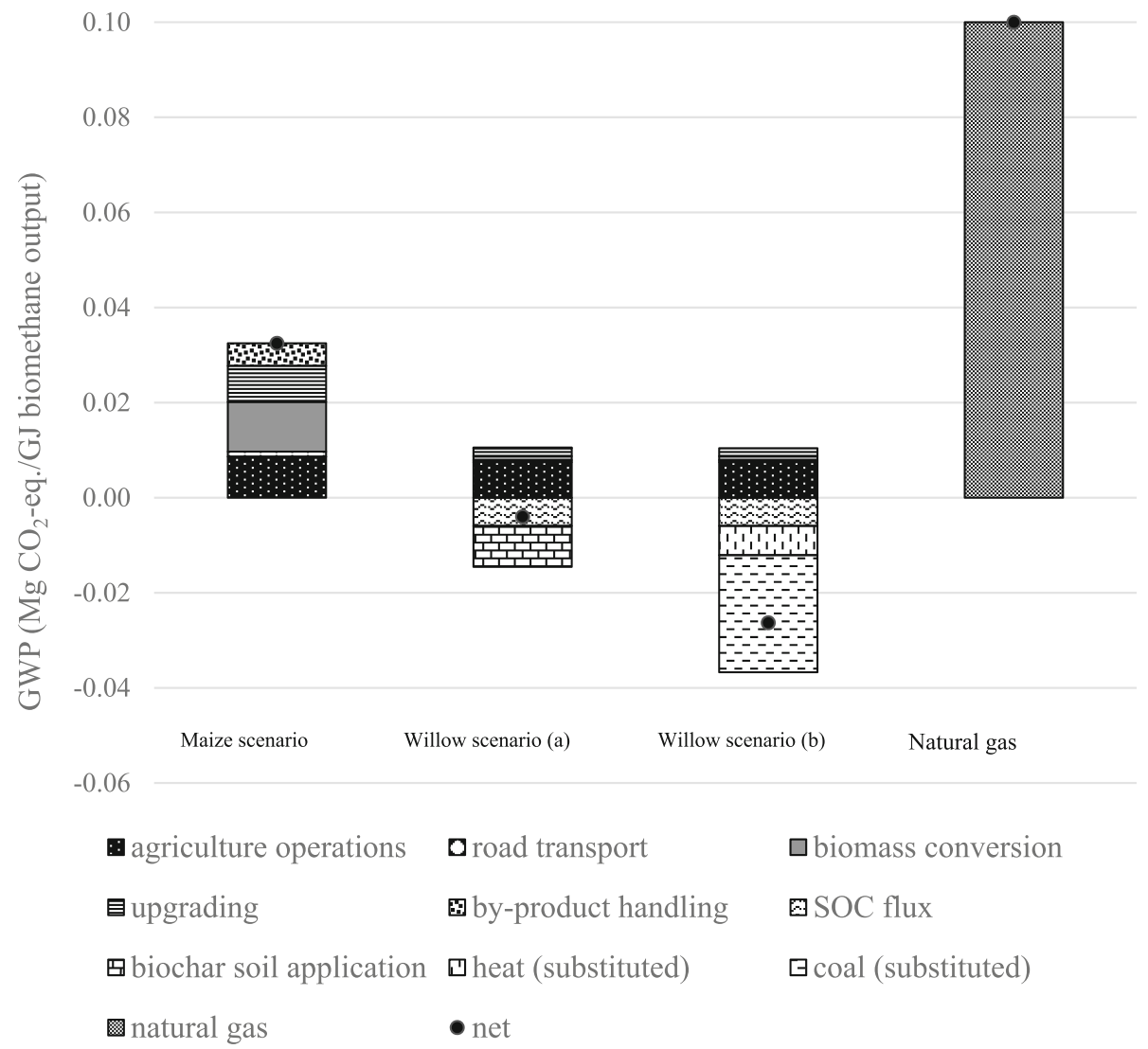

Fig. 9 Climate impact of the reference scenario, the willow scenarios a and b, with physical allocation and system expansion and a natural gasbased system. Data presented in $\mathrm{Mg} \mathrm{CO}_{2}$-eq./GJ biomethane output

sensitivity analysis. Primary energy factors and emission values for the hard coal and NORDEL electricity mix used in the sensitivity analysis are shown in Table 1.

The sensitivity analysis showed that using a hard coal electricity mix considerably increased the PE use for the reference scenario and willow scenario a to 0.26 and $0.14 \mathrm{GJ} / \mathrm{GJ}$ biomethane output, respectively. The climate impact in the reference scenario and willow scenario a increased to 0.063 and $0.024 \mathrm{Mg} \mathrm{CO}_{2}$-eq./GJ biomethane output, respectively.

A $30 \%$ yield increase in the second rotation of willow crop due to new clones with higher nutrient use efficiency and faster growth rate had a considerable effect on the climate impact. The total reduction in GHG emissions was $-0.011 \mathrm{Mg} \mathrm{CO}$-eq./GJ biomethane output. This potential for climate impact mitigation was the result of an increase in carbon sequestration in the biochar pool in the soil. A 30\% yield increase for maize had no marked effect on the climate impact of the reference scenario. The $30 \%$ yield increase increased the PE input in the reference scenario to $0.22 \mathrm{GJ} / \mathrm{GJ}$ biomethane output but with no significant increase in willow scenario a. A yield decrease gave no significant change in the PE input and climate impact of the two scenarios in relation to other parameters.

Increased methane losses in the upgrading stage to $2 \%$ resulted in an increase in GHG emissions to 0.043 and - $0.002 \mathrm{Mg} \mathrm{CO}$-eq./GJ biomethane output for the reference scenario and willow scenario a, respectively. Reducing the methane losses to $0.1 \%$ by using an amine scrubber instead of a water scrubber reduced the climate impact to 0.031 and $-0.006 \mathrm{Mg} \mathrm{CO}$-eq./GJ biomethane output for the reference scenario and willow scenario a, respectively.

\section{Discussion}

In this analysis, changing land use and conversion technology from using maize in an $\mathrm{AD}$ plant to using willow in a pyrolysis plant when producing biomethane led to a clearly improved energy performance and reduced the climate impact from a land use perspective. With 52\% less energy input, the willow scenario had almost double 


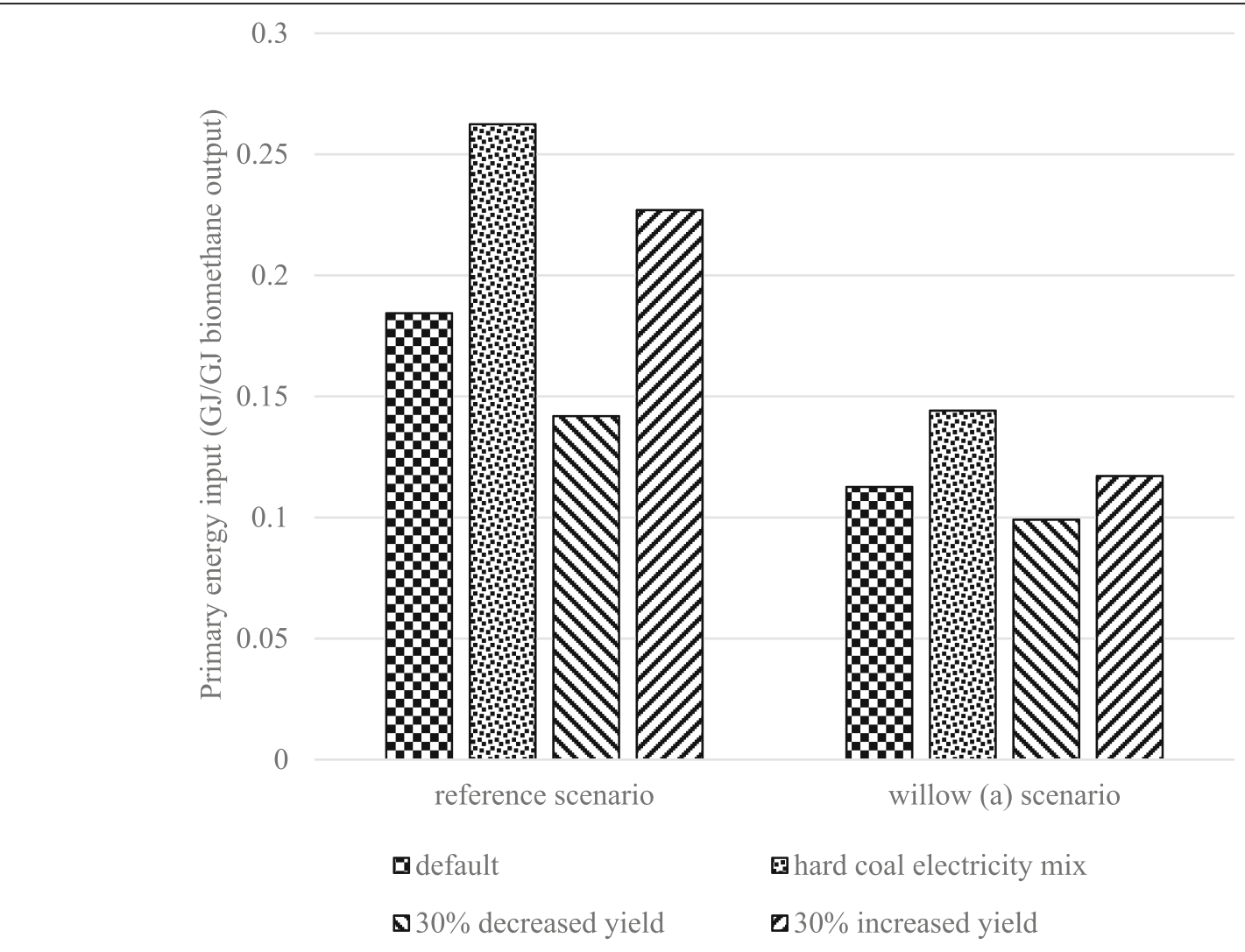

Fig. 10 Results of sensitivity analysis on primary energy (PE) inputs to the reference scenario and willow scenario a. Sensitivity analysis of primary energy inputs with different electricity mix (hard coal), 30\% increased crop yield, and 30\% decreased crop yield for the two scenarios studied

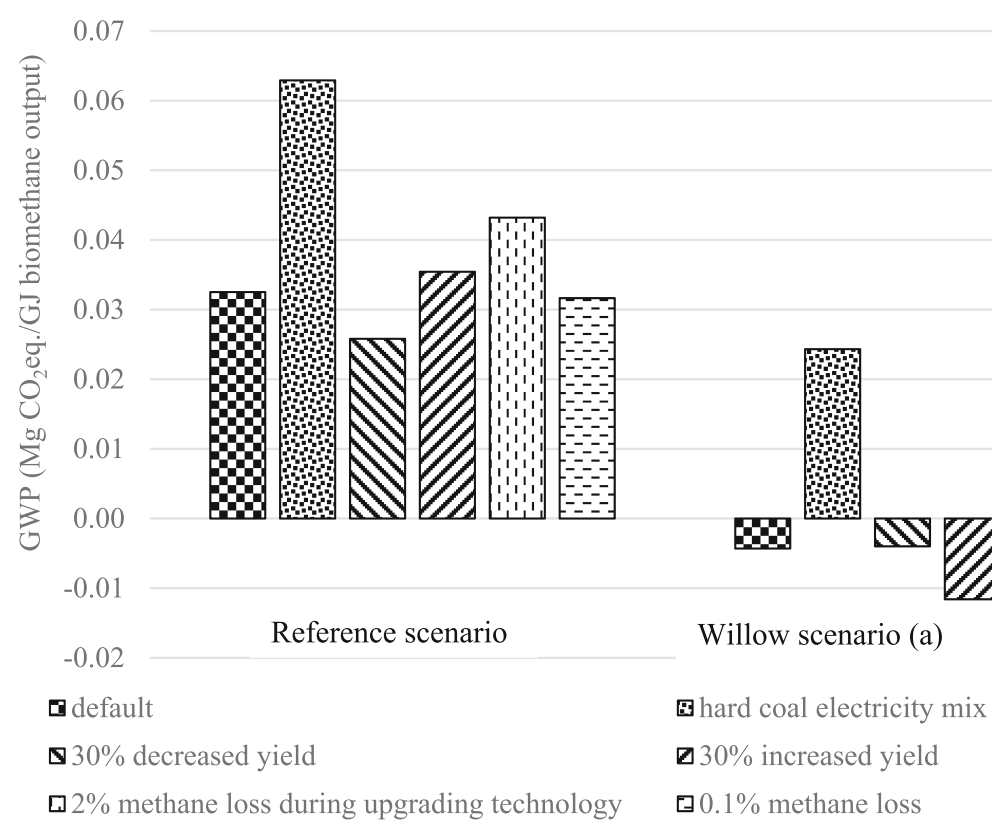

Fig. 11 Results of sensitivity analysis on the climate impact of the reference scenario and in willow scenario a. Sensitivity analysis of climate impacts with different electricity mix (hard coal), $2 \%$ methane loss during upgrading, $0.1 \%$ methane loss during upgrading, 30\% increased crop yield, and 30\% decreased crop yield for the two scenarios studied 
the output to input energy ratio achieved in the reference scenario. Willow scenario a had higher climate impact mitigation potential due to the carbon sink created by the biochar, which is very stable and retains part of the $\mathrm{CO}_{2}$ sequestered in willow biomass for a prolonged period. Furthermore, short-lived SOC increased due to the land use change, which also contributed to mitigating the climate impact of willow scenarios $a$ and $b$. Thus, willow scenarios $a$ and $b$ had the potential to produce biomethane and heat, while counteracting global warming at the same time. However, in the biomethane production scenarios (reference, willow a), substitution of an equivalent amount of natural gas led to a clear reduction in global warming potential.

Considering the different unit processes, agricultural operations had a larger climate impact for maize than for willow. In both scenarios, the major climate impact was related to $\mathrm{N}_{2} \mathrm{O}$ emissions from the soil due to fertilizer use. The actual levels of $\mathrm{N}_{2} \mathrm{O}$ emissions from soil are uncertain, as they are mainly influenced by local parameters. However, the most crucial parameter is the level of nitrogen available in the soil. Precision fertilization and practices to improve the efficiency of plant nitrogen uptake can lead to lower $\mathrm{N}_{2} \mathrm{O}$ emissions [80, 81]. Approximately $14 \%$ of GHG emissions in the reference scenario were related to the handling of the digestate (storage and spreading). Management of digestate is important to minimize emissions from agricultural operations. Management strategies such as shallow injection of liquid digestate reduce nitrogen losses. Storage of digestate is also important, with many studies showing that open-air digestate storage leads to high levels of $\mathrm{CH}_{4}$ emissions. These could be avoided by storing the digestate in covered tanks and capturing the methane generated [62]. The energy intensity of machinery in agricultural operations such as field preparation and sowing, and related diesel consumption, was much higher in the annual maize cropping system than in the perennial willow cropping system. According to [82], maize cultivation requires high mechanical and chemical inputs, especially to combat weeds and pests. Options to reduce the high energy and material inputs to the maize agro-ecosystem include a careful choice of variety, cultural control measures, biological control, and optimization of pesticide application techniques [83].

Biomass conversion and upgrading to biomethane in the willow scenarios had a much lower energy input than in the reference scenario. This was mainly due to the lower electricity use and efficient heat recycling within the pyrolysis reaction processes (e.g., pyrolysis, fuel synthesis, and reformer), while the AD in the reference scenario required much electricity to pump and stir the slurry. The GWP was considerably lower for pyrolysis, which was the biomass conversion step in the willow scenarios. This was mainly due to no methane emissions from the process units (i.e., pyrolysis reactor, pre-reformer, methanation). The upgrading unit contributed to the climate impact mainly due to methane slip and electricity use. In this study, a water scrubber with specific power consumption of $\sim 0.2 \mathrm{kWh} / \mathrm{Nm}^{3}$ was assumed, since it is the dominant upgrading technology used during the past decade, with $40 \%$ market share [84]. The PE input per hectare and year to the upgrading of biogas was eightfold higher in the reference scenario than in the willow scenarios. This could be due to the methanation of $\mathrm{CO}_{2}$ and reverse water-gas shift reactions over the pyrolysis gas in the fuel synthesis step, which converts a large part of the gas to $\mathrm{CH}_{4}$ before entering the upgrading unit. The $\mathrm{CH}_{4}$ loss, which was set to $1 \%$ of the biomethane produced in the upgrading of biogas, was an important contributor to GWP in the reference scenario. With an increase in the methane slip to $2 \%$, the GWP increased considerably. An option to reduce the PE input and the methane emissions could be to choose an amine scrubber, which has a significantly lower electricity demand $\left(\sim 0.12-0.14 \mathrm{kWh} / \mathrm{Nm}^{3} \mathrm{de}-\right.$ pending on plant size) and a methane slip of $\sim 0.1 \%$ [85], but an external heat requirement for regeneration of the amine solution of about $0.55 \mathrm{kWh} / \mathrm{Nm}^{3}$ [84]. However, setting the methane loss to $0.1 \%$ in the sensitivity analysis did not significantly reduce the GWP in the reference scenario.

Heat and biochar, co-products of the willow pyrolysis, have alternative uses where they can substitute fossil fuels. In willow scenario b, the climate impact was lower when the biochar was used for substituting fossil coal rather than as a soil amendment (willow scenario a). This was mainly due to the high climate impact related to the production, distribution, and especially use of coal. Heat produced from a natural gas-based CHP also had a significantly higher climate impact than heat produced through willow pyrolysis. The sensitivity analysis showed that the PE input and the climate impact in both scenarios were most influenced by changing the electricity source to a mix based on hard coal. Choice of electricity mix also had a considerable impact on the results of our previous LCA studies of bioenergy scenarios [52, 86]. Changing the origin of electricity was the only factor in the sensitivity analysis that gave a positive GWP value in willow scenario a.

In this study, we assumed a biomethane plant based on an existing maize cropping system with a steady-state soil carbon level in the reference scenario. Transition to a willow-based system thus led to a direct land use change but not an indirect land use change since the product from the land did not change. Agricultural land dedicated to biofuel production should nevertheless be used in an energy-efficient manner, considering all potential climate 
impacts. Overall, the results from the present analysis show that transition from a maize-based to a willow-based biomethane production system would improve the energy performance and has the potential to mitigate global warming by introducing soil carbon sequestration. However, there are many uncertainties associated with the soil emissions models (e.g., biogenic carbon flux and $\mathrm{N}_{2} \mathrm{O}$ soil emissions) and with the accuracy of the input data. Biogenic carbon dynamics are complex, and often, there are few empirical data available [87]. There are also large uncertainties related to the estimation of $\mathrm{N}_{2} \mathrm{O}$ emissions in climate impact assessments of crops used for biofuels. The IPCC default values [78] used for estimating these emissions are general values which do not consider siteand crop-specific conditions.

Many studies have applied LCA perspectives for assessing the energy balance and climate impact of bioenergy systems (e.g., [53]). However, the wide variation in systems borders, scope, feedstock, etc. complicates the comparison of the results of different studies.

Furthermore, the economic feasibility of systems is important and is likely to be a strong constraining factor when trying to implement pyrolysis instead of $\mathrm{AD}$. While this study was based on modeling, the findings suggest incentives for further technical development and studies regarding pyrolysis of short-rotation coppice willow. Moreover, other environmental impact categories, such as eutrophication, acidification, and ecotoxicity potential, would be of interest in future studies, especially considering the emissions from pesticides and chemicals used in crop cultivation. In efforts to assess the readiness of future technological development and implementation, life cycle cost assessments (LCCs) and technical assessments are needed in order to provide better decision support.

\section{Conclusions}

The transition from maize-based anaerobic digestion to a willow-based pyrolysis system for biomethane production led to increased energy performance and negative global warming potential. Application of biochar to the soil in the willow scenario contributed significantly to counteracting emissions of GHGs. However, when a hard coal electricity mix was considered instead of the Nordic electricity mix, the willow pyrolysis scenario had no net negative climate impact. Both biomethane scenarios reduced the climate impact in comparison with a fossil natural gas-based system.

\section{Additional file}

Additional file 1: Table S1. Agricultural operations and inputs in maize cultivation, data presented per ha and year. Table S2. Yearly agricultural operations and inputs in willow cultivation, data presented per ha and year. Table S3. Primary energy (PE) use and greenhouse gas (GHG) emissions from the production of different inputs to agricultural operations. Figure S1. Energy and mass inputs/outputs to the biomass conversion plant and gas upgrading in the willow scenario, data presented per MW. Table S4. Energy demand/supply of the pyrolysis plant in the willow scenarios, a calculation based on [29], data presented per MW. Table S5. Input values used in ICBM for modeling soil organic carbon (SOC) pools in the reference and willow scenarios, data presented per $\mathrm{Mg}$ and ha. (DOCX $80 \mathrm{~kb}$ )

\section{Abbreviations}

AD: Anaerobic digestion; C: Carbon; $\mathrm{CH}_{4}$ : Methane; $\mathrm{CO}$ : Carbon monoxide; $\mathrm{CO}_{2}$ : Carbon dioxide; DM: Dry matter; ER: External energy ratio;

FU: Functional unit; GHG: Greenhouse gas; GWP: Global warming potential;

ICBM: Introductory carbon balance model; IPCC: International panel on climate change; ISO: International standard organization; K: Potassium; LCA: Life cycle assessment; LHV: Low heating value; N: Nitrogen; $\mathrm{N}_{2} \mathrm{O}$ : Nitrous oxide; P: Phosphorus; PE: Primary energy; SOC: Soil organic carbon; SRC: Short rotation coppice; TS: Total solids; WC: Water content; WW: Wet weight

\section{Acknowledgements}

Not applicable.

\section{Funding}

Not applicable.

\section{Availability of data and materials}

Data used as support for statements in the text and links to publicly available data can be found in the list of references. Original data supporting the results reported are published in Supplementary Material (SM) to this paper.

\section{Authors' contributions}

$\mathrm{NE}, \AA \mathrm{A} N$, and PAH supervised the work. EAM collected the data, carried out the LCA study, and wrote the paper, with contributions from EN, $\AA \mathrm{N}$, and $\mathrm{PAH}$. All authors read and approved the final manuscript.

Ethics approval and consent to participate

Not applicable.

Consent for publication

Not applicable.

Competing interests

The authors declare that they have no competing interests.

\section{Publisher's Note}

Springer Nature remains neutral with regard to jurisdictional claims in published maps and institutional affiliations.

Received: 18 May 2018 Accepted: 25 January 2019

Published online: 22 February 2019

\section{References}

1. Persson T, Baxter D (2015) IEA Bioenergy Task 37: Country Reports Summary 2014. IEA1. 1 bioenergy. ISBN 978-1-910154-11-3

2. Lönnqvist $T$ (2017). Biogas in Swedish transport-a policy-driven systemic transition (Doctoral dissertation), KTH Royal Institute of Technology, Stockholm. ISBN 978-91-7729-389-7

3. SEA (2016), Energy indicators ER 2016:10, Swedish Energy Agency, Eskilstuna

4. Amon T, Kryvoruchko V, Amon B, Bodiroza V, Zollitsch W, Boxberger J (2006) Biogaserzeugung aus Energiemais. LANDTECHNIK-Agric Eng 61(2):86-87

5. Hartmann JK (2006) Life-cycle-assessment of industrial scale biogas plants (Doctoral dissertation). Göttingen State and University Library, Göttingen

6. Börjesson P, Prade T, Lantz M, Björnsson L (2015) Energy crop-based biogas as vehicle fuel-the impact of crop selection on energy efficiency and greenhouse gas performance. Energies 8(6):6033-6058

7. Pöschl M, Ward S, Owende P (2010) Evaluation of energy efficiency of various biogas production and utilization pathways. Appl Energy 87(11):3305-3321 
8. Eckersten $H$, Herrmann A, Kornher A, Halling M, Sindhøj E, Lewan E (2012) Predicting silage maize yield and quality in Sweden as influenced by climate change and variability. Acta Agriculturae Scandinavica, Section B-Soil Plant Sci 62(2):151-165

9. Menardo S, Airoldi G, Cacciatore V, Balsari P (2015) Potential biogas and methane yield of maize stover fractions and evaluation of some possible stover harvest chains. Biosyst Eng 129:352-359

10. Vaneeckhaute C, Meers E, Michels E, Buysse J, Tack FMG (2013) Ecological and economic benefits of the application of bio-based mineral fertilizers in modern agriculture. Biomass Bioenergy 49:239-248

11. Makádi M, Tomócsik A, Orosz V (2012) Chapter 14: digestate: a new nutrient source-review. In: Kumar S (ed) Biogas. InTech, Rijeka

12. Gunaseelan VN (1997) Anaerobic digestion of biomass for methane production: a review. Biomass Bioenergy 13(1-2):83-114

13. Wagner AO, Schwarzenauer T, Illmer P (2013) Improvement of methane generation capacity by aerobic pre-treatment of organic waste with a cellulolytic Trichoderma viride culture. J Environ Manag 129:357-360

14. Amin FR, Khalid H, Zhang H, u Rahman S, Zhang R, Liu G, Chen C (2017) Pretreatment methods of lignocellulosic biomass for anaerobic digestion. AMB Express 7(1):72

15. Cambero C, Sowlati T (2014) Assessment and optimization of forest biomass supply chains from economic, social and environmental perspectives-a review of literature. Renew Sust Energ Rev 36:62-73

16. Strauch S, Schulzke T, Jochum O (2014) Alternative ways of biomethane production - a SWOT analysis. The Biomethane Guide for Decision Makers, Green Gas Grids. Oberhausen

17. Wagner H, Wulf C, Kaltschmitt M (2015) Polygeneration of SNG, heat and power based on biomass gasification and water electrolysis-concepts and their assessment. Biomass Conversion Biorefinery 5(1):103-114

18. Patel M, Zhang X, Kumar A (2016) Techno-economic and life cycle assessment on lignocellulosic biomass thermochemical conversion technologies: a review. Renew Sust Energ Rev 53:1486-1499

19. Balat M, Balat M, Kirtay E, Balat H (2009) Main routes for the thermoconversion of biomass into fuels and chemicals. Part 1: pyrolysis systems. Energy Convers Manag 50(12):3147-3157

20. Lerkkasemsan N (2017) Fuzzy logic-based predictive model for biomass pyrolysis. Appl Energy 185:1019-1030

21. Laird DA (2008) The charcoal vision: a win-win-win scenario for simultaneously producing bioenergy, permanently sequestering carbon, while improving soil and water quality. Agron J 100(1):178-181. https://doi. org/10.2134/agronj2007.0161

22. Shackley S, Carter S, Sims K, Sohi S (2011) Expert perceptions of the role of biochar as a carbon abatement option with ancillary agronomic and soilrelated benefits. Energy Environ 22(3):167-187. https://doi.org/10.1260/0958$305 \times .22 .3 .167$

23. Lehmann J (2007) A handful of carbon. Nature 447(7141):143. https://doi. org/10.1038/447143a

24. Roberts KG, Gloy BA, Joseph S, Scott NR, Lehmann J (2009) Life cycle assessment of biochar systems: estimating the energetic, economic, and climate change potential. Environ Sci Technol 44(2):827-833. https://doi.org/ 10.1021/es902266r

25. Rondon MA, Lehmann J, Ramírez J, Hurtado M (2007) Biological nitrogen fixation by common beans (Phaseolus vulgaris L.) increases with bio-char additions. Biol Fertil Soils 43(6):699-708. https://doi.org/10.1007/s00374-0060152-z

26. Kimetu JM, Lehmann J, Ngoze SO, Mugendi DN, Kinyangi JM, Riha S et al (2008) Reversibility of soil productivity decline with organic matter of differing quality along a degradation gradient. Ecosystems 11(5):726-739. https://doi.org/10.1007/s10021-008-9154-z

27. Ladanai S, Vinterbäck J (2010). Biomass for energy versus food and feed, land use analyses and water supply (no. 022). Technical report. Institutionen för energi och teknik, Sveriges lantbruksuniversitet (SLU), Uppsala (online: https:// pub.epsilon.slu.se/5562/1/ladanai_et_al_110104.pdf). Accessed Oct 2017

28. Peters JF, Iribarren D, Dufour J (2015) Biomass pyrolysis for biochar or energy applications? A life cycle assessment. Environ Sci Technol 49(8): 5195-5202. https://doi.org/10.1021/es5060786

29. Görling M, Larsson M, Alvfors P (2013) Bio-methane via fast pyrolysis of biomass. Appl Energy 112:440-447. https://doi.org/10.1016/j. apenergy.2013.01.002

30. Voets T, Kuppens T, Cornelissen T, Thewys T (2011) Economics of electricity and heat production by gasification or flash pyrolysis of short rotation coppice in Flanders (Belgium). Biomass Bioenergy 35(5):1912-1924. https:// doi.org/10.1016/j.biombioe.2011.01.034

31. Ericsson N, Sundberg C, Nordberg $\AA$, Ahlgren S, Hansson PA (2017) Timedependent climate impact and energy efficiency of combined heat and power production from short-rotation coppice willow using pyrolysis or direct combustion. GCB Bioenergy 9(5):876-890

32. Weih M, Nordh NE (2005) Determinants of biomass production in hybrid willows and prediction of field performance from pot studies. Tree Physiol 25(9):1197-1206

33. Mola-Yudego B, Pelkonen P (2008) The effects of policy incentives in the adoption of willow short rotation coppice for bioenergy in Sweden. Energy Policy 36(8):3062-3068

34. Mola-Yudego B, González-Olabarria JR (2010) Mapping the expansion and distribution of willow plantations for bioenergy in Sweden: lessons to be learned about the spread of energy crops. Biomass Bioenergy 34(4):442-448

35. Greenhalf CE, Nowakowski DJ, Harms AB, Titiloye JO, Bridgwater AV (2012) Sequential pyrolysis of willow SRC at low and high heating ratesimplications for selective pyrolysis. Fuel 93:692-702

36. Rosenqvist H, Roos A, Ling E, Hektor B (2000) Willow growers in Sweden. Biomass Bioenergy 18(2):137-145 https://doi.org/10.1016/S09619534(99)00081-1

37. Jordbruket I siffror (2017) Odling av salix, poppel och hybriasp 20052017. Available via https://jordbruketisiffror.wordpress.com/2017/08/11/ odling-av-salix-poppel-och-hybriasp-2005-2017/. Accessed 10 Feb 2018

38. Volk TA, Verwijst T, Tharakan PJ, Abrahamson LP, White EH (2004) Growing fuel: a sustainability assessment of willow biomass crops. Front Ecol Environ 2(8): 411-418. https://doi.org/10.1890/1540-9295(2004)002[0411:gfasao]2.0.co;2

39. ISO (2006) Environmental management-life cycle assessment-principles and framework (ISO 14040:2006). European Committee for Standardization, Brussels

40. ISO (2006) Environmental management-life cycle assessment-requirements and guidelines (ISO 14044:2006). European Committee for Standardization, Brussels

41. Baumann H, Tillman AM (2004) The hitch hiker's guide to LCA (Life Cycle Assessment): an orientation in Life Cycle Assessment methodology and application. Studentlitteratur

42. Kuponen K (2016) Challenges of an LCA based decision making framework - the case of EU sustainability criteria for biofuels, PhD thesis. Department of Mechanical Engineering, Aalto University, Finland ISBN: 978-952-60-6795-7 (Aalto, electronic)

43. Pavlovskaia E (2014) Sustainability criteria: their indicators, control, and monitoring (with examples from the biofuel sector). Environ Sci Eur 26(1):17 https://doi.org/10.1186/s12302-014-0017-2

44. Bourguignon D (2015) EU biofuels policy: dealing with indirect land use change. European Parliamentary Research Service, Brussels

45. Giampietro M, Ulgiati S, Pimentel D (1997) Feasibility of large-scale biofuel production. 1997. BioScience 47(9):587-600. https://doi.org/10.2307/1313165

46. Timilsina G (2013) Biofuels in the long-run global energy supply mix for transportation. Phil. Trans. R. Soc. A 372(2006):20120323

47. Gnansounoua E, Dauriatb A, Villegasa J, Panichellia L (2009) Life cycle assessment of biofuels: energy and greenhouse gas balances, 2009. Bioresour Technol 100(21):4919-4930. https://doi.org/10.1016/j.biortech.2009.05.067

48. Anderson-Teixeira KJ, Davis SC, Masters MD, Delucia EH (2009) Changes in soil organic carbon under biofuel crops. GCB Bioenergy 1:75-96. https://doi. org/10.1111/j.1757-1707.2008.01001.x

49. Schmer MR, Jin VL, Wienhold BJ (2015) Sub-surface soil carbon changes affects biofuel greenhouse gas emissions. Biomass Bioenergy 81:31-34

50. Nilsson D (1995) Transportation work and energy requirements for haulage of straw fuels. A comparison between the plants at Såtenäs and Svalöv. Swedish J. Agric. Res 25:137-141

51. Frischknecht R, Althaus HJ, Bauer C, Doka G, Heck T, Jungbluth N, Kellenberger D, Nemecek T (2007) The environmental relevance of capital goods in life cycle assessments of products and services. Int J Life Cycle Assessment 12(1):7-17. https://doi.org/10.1065/lca2007.02.308

52. Moghaddam EA, Ahlgren S, Hulteberg C, Nordberg $\AA$ (2015) Energy balance and global warming potential of biogas-based fuels from a life cycle perspective. Fuel Process Technol 132:74-82. https://doi.org/10.1016/j. fuproc.2014.12.014

53. Cherubini F, Strømman AH (2011) Life cycle assessment of bioenergy systems: state of the art and future challenges. Bioresource Technol 102(2): 437-451. https://doi.org/10.1016/j.biortech.2010.08.010 
54. Union E (2009) Directive 2009/28/EC of the European Parliament and of the Council of 23 April 2009 on the promotion of the use of energy from renewable sources and amending and subsequently repealing Directives 2001/77/EC and 2003/30/EC. Official Journal of the European Union, 5, 2009

55. Ecoinvent (2017) Ecoinvent Centre, ecoinvent data v3.3. Swiss Centre for Life Cycle Inventories, Dübendorf

56. Arnesson A, Rustas BO, Nadeau E, Swensson C (2009) Majsproduktion på gårdar i södra Sverige-odling, konservering och foderkvalitet (Maize production on farms in southern Sweden - cultivation, preservation and feed quality). Swedish University of Agricultural Sciences (SLU), Skara

57. Mayer F, Gerin PA, Noo A, Lemaigre S, Stilmant D, Schmit T et al (2014) Assessment of energy crops alternative to maize for biogas production in the Greater Region. Bioresour Technol 166:358-367

58. Strömberg B, Herstad Svärd S (2012) The Fuel Handbook (Bränslehandboken), Värmeforsk rapport 1234, Värmeforsk. Stockholm

59. Rehl T, Lansche J, Müller J (2012) Life cycle assessment of energy generation from biogas - attributional vs. consequential approach, 2012. Renew Sustain Energ Rev 16:3766-3775. https://doi.org/10.1016/j. rser.2012.02.072

60. Meixner K, Fuchs W, Valkova T, Svarda K, Loderer C, Neureiter M, Bochmann G, Drosg B (2015) Effect of precipitating agents on centrifugation and ultrafiltration performance of thin stillage digestate. Sep Purif Technol 145:154-160. https://doi.org/10.1016/j. seppur.2015.03.003

61. Gissén C, Prade T, Kreuger E, Nges IA, Rosenqvist H, Svensson SE et al (2014) Comparing energy crops for biogas production-yields, energy input and costs in cultivation using digestate and mineral fertilisation. Biomass Bioenergy 64:199-210. https://doi.org/10.1016/j.biombioe.2014.03.061

62. Whiting A, Azapagic A (2014) Life cycle environmental impacts of generating electricity and heat from biogas produced by anaerobic digestion. Energy 70:181-193. https://doi.org/10.1016/j.energy.2014.03.103

63. Herrmann C, Heiermann M, Idler C (2011) Effects of ensiling, silage additives and storage period on methane formation of biogas crops. Bioresource Technol 102(8):5153-5161. https://doi.org/10.1016/j.biortech.2011.01.012

64. Ericsson N, Nordberg Å, Sundberg C, Ahlgren S, Hansson PA (2014) Climate impact and energy efficiency from electricity generation through anaerobic digestion or direct combustion of short rotation coppice willow. Applied Energy 132:86-98

65. Nilsson D, Larsolle A, Nordh NE, Hansson PA (2017) Dynamic modelling of cut-and-store systems for year-round deliveries of short rotation coppice willow. Biosyst Eng 159:70-88

66. Gustafsson J, Larsson S, Nordh NE (2006) Manual för Salixodlare Report (Manual for Salix growers Report). Lantmännen Agroenergi AB, Örebro

67. Boerrigter H, Deurwaarder EP, Bergman PCA, van Paasen SVB, van Ree R (2004) Thermal bio-refinery; high-efficient integrated production of renewable chemicals, (transportation) fuels, and products from biomass, 2004. Presented at "the 2nd World Conference and Technology Exhibition on Biomass for Energy, Industry and Climate Protection" in Rome, Italy, 10-14 May 2004 (online: ftp://ftp.ecn.nl/pub/www/library/report/2004/rx04044.pdf). Accessed Nov 2018

68. Civitarese V, Spinelli R, Barontini M, Gallucci F, Santangelo E, Acampora A, Scarfone A, Del Giudice A, Pari L (2015) Open-air drying of cut and windrowed short-rotation poplar stems. BioEnergy Res 8(4):1614-1620

69. SEA (2006) Effektivare primärenergianvändning - En uppföljning av måluppfyllelse avseende EG-direktivet om effektivare slutanvändning av energi och om energitjänster mellan åren 1991 till 2004. (More efficient primary energy use - A follow-up of goal fulfillment regarding the EC directive on more efficient end use of energy and on energy services between 1991 and 2004). Report ER 2006:32. Swedish Energy Agency

70. Murphy D, Hall C, Dale M, Cleveland C (2011) Order from chaos: a preliminary protocol for determining the EROI of fuels. Sustainability 3(10):1888-1907

71. Stocker TF, Qin D, Plattner GK, Alexander LV, Allen SK, Bindoff NL et al (2013) Technical summary. In climate change 2013: the physical science basis. Contribution of Working Group I to the Fifth Assessment Report of the Intergovernmental Panel on Climate Change 33-11. Cambridge University Press, Paris

72. Andrén O, Kätterer T, Karlsson T (2004) ICBM regional model for estimations of dynamics of agricultural soil carbon pools. Nutr Cycl Agroecosyst 70(2):231-239

73. Ericsson N (2015) Time-dependent climate impact of short rotation coppice willow-based systems for electricity and heat production, (Doctoral dissertation), Swedish University of Agricultural Sciences (SLU), Uppsala. ISBN 978-91-576-8390

74. Zimmerman AR (2010) Abiotic and microbial oxidation of laboratoryproduced black carbon (biochar). Environ Sci Technol 44:1295-1301

75. Berglund M, Börjesson P (2006) Assessment of energy performance in the life-cycle of biogas production. Biomass Bioenergy 30:254-266. https://doi. org/10.1016/j.biombioe.2005.11.011

76. Hoyer K, Hulteberg C, Svensson M, Jernberg J, Nørregård Ø (2016) Biogas upgrading - technical Review. Energiforsk. ISBN 978-91-7673-275-5

77. Rodhe L, Nordberg $\AA$ (2011) Greenhouse gas emissions from the storage of liquid and solid manure and abatement strategies. Conference paper: Emissionen der Tierhaltung. Treibhausgase, Umweltbewertung, Stand det Techik 491:206-216

78. De Klein C, Novoa RS, Ogle S, Smith KA, Rochette P, Wirth TC, ... \& Williams SA (2006) N2O emissions from managed soils, and CO2 emissions from lime and urea application. IPCC guidelines for National greenhouse gas inventories, prepared by the National greenhouse gas inventories programme, 4, 1-54

79. Benjaminsson J, Nilsson R (2009) Distributionsformer för biogas och naturgas i Sverige. Rapport på uppdrag av Energigas Sverige, Grontmij, Stockholm

80. Sogbedji IM, van Es HM, Yang CL, Geohring LD, Magdoff FR (2000) Nitrate leaching and nitrogen budget as affected by maize nitrogen rate and soil type. J Environ Qual 29(6):1813-1820. https://doi.org/10.2134/jeq2000. $00472425002900060011 x$

81. Snyder CS, Bruulsema TW, Jensen TL, Fixen PE (2009) Review of greenhouse gas emissions from crop production systems and fertilizer management effects. Agric Ecosyst Environ 133:247-266

82. Melander B, Munier-Jolain N, Charles R, Wirth J, Schwarz J, Van der Weide R, Bonin L, Jensen PK, Kudsk P (2012) Weed Technology 27(1):231-240. https:// doi.org/10.1614/WT-D-12-00066.1

83. Meissle M, Mouron P, Musa T, Bigler F, Pons X, Vasileiadis VP et al (2010) Pests, pesticide use and alternative options in European maize production: current status and future prospects. J Appl Entomol 134(5):357-375. https:// doi.org/10.1111/j.1439-0418.2009.01491.x

84. Bauer F, Persson T, Hulteberg C, Tamm D (2013) Biogas upgradingtechnology overview, comparison and perspectives for the future. Biofuels Bioprod Biorefin 7(5):499-511. https://doi.org/10.1002/bbb.1423

85. Starr K, Gabarrell X, Villalba G, Talens L, Lombardi L (2012) Life cycle assessment of biogas upgrading technologies. Waste Manag 32(5):991-999. https://doi.org/10.1016/j.wasman.2011.12.016

86. Moghaddam EA, Ahlgren S, Nordberg $\AA$ (2016) Assessment of novel routes of biomethane utilization in a life cycle perspective. Front Bioeng Biotechnol 4:89. https://doi.org/10.3389/fbioe.2016.00089

87. Lamers $P$, Junginger $M(2013)$ The 'debt' is in the detail: a synthesis of recent temporal forest carbon analyses on woody biomass for energy. Biofuels Bioprod Biorefin 7(4):373-385. https://doi.org/10.1002/bbb.1407

Ready to submit your research? Choose BMC and benefit from:

- fast, convenient online submission

- thorough peer review by experienced researchers in your field

- rapid publication on acceptance

- support for research data, including large and complex data types

- gold Open Access which fosters wider collaboration and increased citations

- maximum visibility for your research: over $100 \mathrm{M}$ website views per year

At $\mathrm{BMC}$, research is always in progress.

Learn more biomedcentral.com/submissions 